\title{
18. UPPER EOCENE SEQUENCE STRATIGRAPHY AND THE ABSECON INLET FORMATION, NEW JERSEY COASTAL PLAIN ${ }^{1}$
}

\author{
James V. Browning, ${ }^{2}$ Kenneth G. Miller, ${ }^{2,3}$ and Laurel M. Bybell ${ }^{4}$
}

\begin{abstract}
We evaluate the age, benthic biofacies, and sequence stratigraphy of thick and well-recovered upper Eocene sediments from the New Jersey Coastal Plain. These strata are herein defined as a lithostratigraphic unit and named the Absecon Inlet Formation. The formation is divided into upper and lower portions. At its type locality in the Atlantic City borehole, the lower portion of the Absecon Inlet Formation consists of $171 \mathrm{ft}(52 \mathrm{~m})$ of glauconitic silts and silty clays and is assigned to calcareous nannoplankton Zone NP 19/20 (late Eocene). At the ACGS\#4 borehole, the type locality for its upper portion, the formation consists of slightly sandy clays and is assigned to Zone NP 21 (late Eocene to earliest Oligocene). The continuous stratigraphic occurrence of Hantkenina spp. in these sediments is evidence of an Eocene age for the upper portion of the Absecon Inlet Formation. Benthic foraminiferal analysis reveals five biofacies in the Absecon Inlet Formation, three of which can be related to paleowater depth: a Siphonina biofacies inhabited water depths of $75 \pm 25 \mathrm{~m}$; a Cibicidoides biofacies inhabited water depths of $100 \pm 30$ $\mathrm{m}$; and a Globobulimina biofacies inhabited water depths of $125 \pm 30 \mathrm{~m}$. In addition, a Gyroidinoides biofacies occurs only within transgressive systems tracts. A Bulimina jacksonensis biofacies is believed to be related to a circum-Atlantic paleoceanographic event unrelated to depth changes on the shelf. Gamma-log, lithologic, and faunal/floral data are used to interpret the sequence stratigraphic architecture of the Absecon Inlet Formation. We conclude that the timing of unconformities (sequence boundaries) and maximum flooding surfaces within the Absecon Inlet Formation is consistent with the eustatic record of Exxon and the global $\delta^{18} \mathrm{O}$ record.
\end{abstract}

\section{INTRODUCTION}

An important goal of the New Jersey Coastal Plain Drilling Project (Ocean Drilling Program [ODP] Leg 150X) is to document Paleogene sedimentary sequences and relate them to the Haq et al. (1987) eustatic record and the $\delta^{18} \mathrm{O}$ proxy for sea-level change (see Miller, Chapter 1, this volume, for an explanation). Sequence stratigraphy is a potentially powerful method for interpreting the stratigraphic record. First proposed by Vail and Mitchum (1977) and refined by Posamentier et al. (1988), sequence stratigraphy "is the study of sediments and sedimentary rocks in terms of repetitively arranged facies and associated stratal geometry" (Christie-Blick and Driscoll, 1995, p. 451). Sequence stratigraphy recognizes that shallow water sediments are deposited in distinctive packets bounded by unconformities. Because these unconformities separate older from younger rocks, sequences have both time and genetic significance (Christie-Blick and Driscoll, 1995).

Sequence formation is interpreted to be controlled by eustatic change with the bounding unconformities being created during the maximum rate of sea-level fall (Posamentier et al., 1988; ChristieBlick et al., 1990) or, in some situations, early in the relative fall (Reynolds et al., 1991). Oligocene and Miocene sequence boundaries on the New Jersey slope and coastal plain correlate with the $\delta^{18} \mathrm{O}$ proxy for sea-level change, indicating that sequence boundary formation was driven by glacioeustasy (Miller et al., 1996b). In contrast to the Miocene, the Paleocene to early Eocene were times of warm climates (Wolfe, 1992) and may have been ice free (see Browning et al. [Chapter 17, this volume] for discussion). There is general agreement that ice was present on Antarctica by the earliest Oligocene (Miller et

${ }^{1}$ Miller, K.G., and Snyder, S.W. (Eds.), 1997. Proc. ODP, Sci. Results, 150X: College Station, TX (Ocean Drilling Program).

${ }^{2}$ Department of Geological Sciences, Rutgers University, Piscataway, NJ 08855, U.S.A.

'Lamont-Doherty Earth Observatory of Columbia University, Palisades, NY 10964 U.S.A.

${ }^{4}$ Correspondence author: 926 National Center, U.S. Geological Survey, Reston, VA 22092, U.S.A. lbybell@geochange.er.usgs.gov al., 1991; Zachos et al., 1992), and there is growing evidence that a significant ice sheet had formed on Antarctica by the late middle Eocene (Barron et al., 1991; Browning et al., Chapter 17, this volume). Although we suspect that growth and decay of ice was responsible for the formation of sequence boundaries in the late Eocene, as yet, no attempt has been made to link New Jersey coastal plain sequence boundaries to the $\delta^{18} \mathrm{O}$ record.

The New Jersey coastal plain is an excellent place to study the effects of changing sea-level on sedimentation. It is important to evaluate late Eocene sea-level changes on this margin because of uncertainties in mechanism. The New Jersey Margin was sediment starved and subject to slow thermal subsidence $(<10 \mathrm{~m} / \mathrm{m}$.y.) throughout the Cenozoic (e.g., Steckler and Watts, 1978), and sea-level changes should be readily discernible in the sediments from this margin. However, upper Eocene sediments and benthic foraminiferal faunas are not well documented from the New Jersey Margin because of poor sampling of upper Eocene sections. The three Leg $150 \mathrm{X}$ boreholes recovered a total of $490 \mathrm{ft}(149 \mathrm{~m})$ of upper Eocene sediments that for the first time allow a detailed analysis of faunas and sediments (Fig. 1). The purpose of this paper is to describe the sediments and faunas found in the New Jersey upper Eocene, place them into a sequence stratigraphic framework, and discuss possible mechanisms for sequence boundary formation. We also formally name the Absecon Inlet Formation.

\section{METHODS}

New Jersey Eocene sediments were studied in four boreholes from the coastal plain. The Island Beach, Atlantic City, and Cape May boreholes were drilled as a part of Leg 150X (Miller et al., 1994a, 1994b; Miller, et al., 1996). The Atlantic County Girl Scout Council Camp 4 borehole (ACGS\#4) was drilled by the U.S. Geological Survey and the New Jersey Geological Survey near Mays Landing, New Jersey in 1984 (Owens et al., 1988). Sequence boundaries were based primarily on physical surfaces (including irregular contacts, reworking, bioturbation, and major facies changes), as well as planktonic foraminiferal and calcareous nannofossil biostratigraphy 


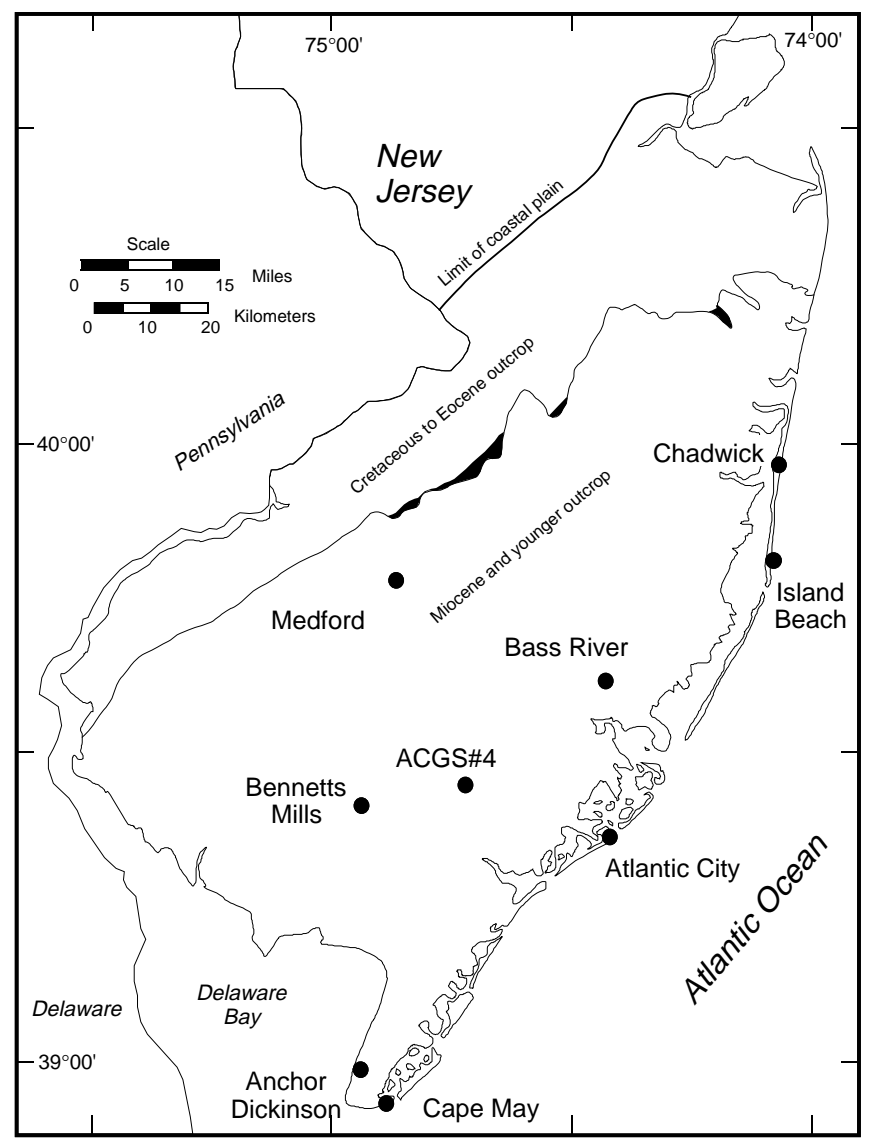

Figure 1. Location map showing locations of major boreholes on the New Jersey Coastal Plain. Dark pattern indicates location of Eocene outcrop (after Enright, 1969).

(Liu et al., Chapter 10, this volume; Miller et al., 1994a; Miller et al., 1996b). Magnetostratigraphic studies in the upper Eocene at these boreholes yielded a weak polarity signal (Van Fossen, Chapter 22, this volume; Miller et al., 1990). Direct ties to the Geomagnetic Polarity Time Scale (GPTS) are difficult because of the possibility of overprinting. The time scale of Berggren et al. (1995) is used throughout.

Recognition of individual systems tracts in the upper Eocene is difficult because of their subtle expression in these fine-grained, deep-water sediments. In the New Jersey coastal plain, lowstand systems tracts (LST) are generally absent and only the transgressive (TST) and highstand (HST) systems tracts have been identified. Typical New Jersey Miocene and Oligocene sequences have sand, often containing glauconite, at the base, interpreted as the TST, overlain by lower HST clays and silts with upper HST sands at the top (Sugarman et al., 1993; Pekar et al., Chapter 15, this volume). The TSTs in the Miocene and Oligocene are generally thin and sequences are dominated by the HST (Miller et al., Chapter 14, this volume; Pekar et al., Chapter 15, this volume). The top of the glauconite in Miocene and Oligocene sequences often coincides with peak abundances of benthic foraminifers, especially Uvigerina. Peak abundances in Uvigerina are commonly associated with peaks in total organic carbon (Miller and Lohmann, 1982), which typically take place during times of maximum flooding (Loutit et al., 1988). In contrast to the Oligocene and Miocene, upper Eocene sequences contain bioturbated clay throughout with little sand. Thin glauconitic intervals are frequently present at the bases of upper Eocene sequences. We cannot determine definitively whether the maximum flooding surface (MFS) and the top of the TST coincides with the glauconitic intervals or if they are higher in the section and coincide with peak abundances of Uvigerina. The HST sands are absent in the upper Eocene sequences probably because of their deposition in deeper water than the Miocene examples of Sugarman et al. (1993).

Samples for benthic foraminiferal biofacies analysis were obtained from the four boreholes. The sampling interval was $5 \mathrm{ft}(1.5 \mathrm{~m})$ in the ACGS\#4 borehole and $\sim 10 \mathrm{ft}(3.0 \mathrm{~m})$ in the other boreholes. Samples of $\sim 20 \mathrm{~cm}^{3}$ were soaked in a sodium metaphosphate solution to disaggregate the sediments. Samples that did not respond to the treatment of sodium metaphosphate were boiled in sodium carbonate. Samples were washed through a $63-\mu \mathrm{m}$ mesh to remove the clay and silt. The dried samples were sieved to obtain the $>150-\mu \mathrm{m}$ fraction, and random samples of $\sim 300$ specimens were picked for quantitative analysis. The 63 - to $150-\mu \mathrm{m}$ fraction was saved for qualitative analysis.

Benthic foraminifers were identified to the species level using the taxonomy of Tjalsma and Lohmann (1983), Jones (1983), Bandy (1949), Enright (1969), Boersma (1984), and Charletta (1980). The data set was normalized to percentages, and Q-mode factor analysis was used to compare variations among the samples. The factors obtained were rotated using a Varimax Factor rotation and Systat 5.2.1 on a Macintosh microcomputer. For this paper, the bathymetric zonation of van Morkhoven et al. (1986) is used: 0-30 m is inner neritic, $30-100 \mathrm{~m}$ is middle neritic, $100-200 \mathrm{~m}$ is outer neritic, and $200-600$ $\mathrm{m}$ is upper bathyal.

\section{PREVIOUS WORK}

Upper Eocene sediments do not crop out in New Jersey. Their existence in the New Jersey Coastal Plain subsurface was first reported by Brown et al. (1972), who found upper Eocene (Jackson age) sediments in four wells drilled at Island Beach, the Anchor Gas-Dickinson I well drilled near Cape May, a well drilled near Chadwick, and a well drilled near Bennetts Mills (Fig. 1). Their study relied on benthic foraminifers and ostracodes for recognition of the upper Eocene, and many of their purported upper Eocene samples may actually be middle Eocene. Problems in sampling (i.e., only rotary cuttings and occasional split-spoon cores were available prior to 1986) and rare pelagic marker taxa have complicated the identification and correlation of upper Eocene strata. For example, Olsson et al. (1980) studied the Anchor Gas-Dickinson I well and found no upper Eocene planktonic foraminifers. In contrast, the Anchor Dickinson and Island Beach boreholes were also examined by Poag (1985), who confirmed the existence of upper Eocene at Anchor Dickinson, but found no planktonic foraminiferal evidence for upper Eocene in the samples at Island Beach. The presence of upper Eocene strata at Anchor Dickinson is confirmed by studies of calcareous nannoplankton (L. Bybell, unpubl. data).

The first detailed description of upper Eocene sediments in New Jersey was by Owens et al. (1988) in the ACGS\#4 borehole drilled near Mays Landing, New Jersey (Fig. 1). This unit, found between 761 and $615 \mathrm{ft}(232$ and $187 \mathrm{~m})$ in the borehole, was informally termed the ACGS Alpha unit. Owens et al. (1988) divided the unit into three subunits. Subunit A, a fine to medium glauconite sand, occurs between 761 and $735 \mathrm{ft}$ (232 and $224 \mathrm{~m}$ ). Subunit B, an oliveblack clayey silt interbedded with slightly to moderately glauconitic, fine sand, occurs between 735 and $695 \mathrm{ft}$ (224 and $212 \mathrm{~m}$ ). Subunit $\mathrm{C}$, a brownish black, laminated, very clayey silt, occurs between 695 and $615 \mathrm{ft}$ (212 and $187 \mathrm{~m}$ ). The environment of deposition was interpreted to be inner to middle shelf, shallower water than the underlying Shark River Formation. The biostratigraphy of the ACGS Alpha unit was examined by Poore and Bybell (1988). The age of the unit, based upon calcareous nannoplankton, spans upper Zone NP 18, Zone NP 19/20 and the lower part of Zone NP 21. Late Eocene plank- 
tonic foraminifers, including Hantkenina spp., continue to $624 \mathrm{ft}$ $(190 \mathrm{~m})$ in the ACGS\#4 borehole. Foraminifers are rare in the upper $9 \mathrm{ft}$ of the ACGS Alpha unit, and the absence of diagnostic Eocene taxa may be caused by nonpreservation.

Miller et al. (1990) examined the upper Eocene stratigraphy in the ACGS\#4 borehole but were unable to improve on the late Eocene age control of Poore and Bybell (1988). The paleomagnetic polarity sequence in these sandier facies could not readily be interpreted, and no attempt was made to correlate to the GPTS. Seven Sr-isotopic age estimates support the conclusion that these are upper Eocene sediments.

Christensen et al. (1995) attempted to refine the sequence stratigraphic interpretations of Miller et al. (1990) using benthic foraminiferal biofacies analysis. They reinterpreted the upper Eocene (Sequence $\mathrm{E}$ of Christensen et al., 1995) to extend from 755 to $615 \mathrm{ft}$ (230.1-187.5 m). Factor analysis in this interval did not reveal stratigraphically distinct factors. Peaks in the abundance of Uvigerina multistriata were used to infer flooding surfaces separating parasequences.

\section{ABSECON INLET FORMATION Lithology}

Upper Eocene sediments are predominantly clays and silts with occasional thin glauconite sand beds. These beds are lithologically distinct from the overlying Oligocene sands and underlying middle Eocene quartz and glauconite sands and sandy clays. The upper Eocene glauconitic silts and silty clays are here designated the Absecon Inlet Formation, and the Leg 150X Atlantic City borehole is designated as the type locality. The type locality for the upper portion of the formation (assigned to calcareous nannoplankton Zone NP 21) is designated at the ACGS\#4 borehole. The upper Eocene at Atlantic City is $171 \mathrm{ft}$ thick (52 m), with $152.9 \mathrm{ft}(46.6 \mathrm{~m} ; 89 \%)$ recovered. At ACGS\#4, the Zone NP 21 section is $71 \mathrm{ft}$ thick $(21.6 \mathrm{~m})$, with nearly $100 \%$ recovery (Owens et al., 1988). Preservation of calcareous nannofossils is excellent in both sections. The name of the formation is derived from the Absecon Inlet, which is adjacent to the Atlantic City drill site.

The Absecon Inlet Formation at the type section at Atlantic City (Fig. 2) overlies the Shark River Formation across a disconformity at $1352 \mathrm{ft}(412.1 \mathrm{~m})$, where slightly glauconitic clays are overlain by highly fossiliferous black clay (Miller et al., 1994a). The unit underlying the Absecon Inlet Formation is variable in lithology. At Island Beach, it consists of pebbly medium- to coarse-grained quartz sand with little clay (the Toms River Member of Enright, 1969). At Atlantic City and ACGS\#4, the underlying lithology is finer grained but still contains glauconite and fine to medium quartz sand with abundant microfossils. This underlying unit, at both boreholes, contains planktonic foraminifers and calcareous nannoplankton of different ages all mixed together. This underlying unit may be stratigraphically equivalent to the Exmore Boulder Bed (Poag et al., 1992) and reflect the effects of an impact event.

At Atlantic City, uniform clays continue up to $1333 \mathrm{ft}$ (406.3 m) where a surface in the core separates silty clays below from glauconitic clays. These glauconitic clays grade to silty clays, and this lithology continues to $\sim 1273 \mathrm{ft}(388.0 \mathrm{~m})$, where the percent quartz and glauconite fine sand increases to $15 \%-20 \%$. This slightly sandier lithology continues to the top of the section, where a disconformity separates the Absecon Inlet Formation clays and silts below from the overlying Oligocene Sewell Point Formation (Pekar et al., Chapter 15, this volume). The Sewell Point Formation contains a shell hash and glauconite sands at its base and overall is much coarser grained than the silts and clays of the Absecon Inlet Formation. The downhole gamma-ray log is very uniform throughout the stratotype and is not helpful in interpreting facies in this formation. The gamma-ray log obtained on cores shows several distinct peaks that may correlate with flooding surfaces (Fig. 2; see Metzger et al., Chapter 6, this volume). Updip, at Island Beach, glauconite sand beds are thicker within the Absecon Inlet Formation, especially at the base.

Based on the absence of Zone NP21, the upper portion of the Absecon Inlet Formation is not represented at Atlantic City (Aubry in Miller et al., 1994a). The upper portion of the formation (Zone NP21) is represented at the ACGS\#4 borehole, where it consists of slightly sandy clay at the base that grades upward to a silty clay at the top of the formation (Fig. 2). Sand is nearly absent from these very finegrained sediments. The base of the upper Absecon Inlet at $695 \mathrm{ft}$ $(211.8 \mathrm{~m})$ is a disconformity separating brownish black clayey silt above from fine to medium glauconite quartz sand below. The upper contact is at $615 \mathrm{ft}(187.5 \mathrm{~m})$ in the borehole, where there is a change from clays below to lowermost Oligocene glauconitic clayey sands above; this is the Mays Landing unit of Owens et al. (1988), which is equivalent to the Sewell Point Formation of Pekar et al. (Chapter 15, this volume).

\section{Age}

The age of the Absecon Inlet Formation is established using planktonic foraminifers, calcareous nannoplankton, and Sr-isotopic age estimates. The formation overlies a biostratigraphically mixed layer in which upper Eocene calcareous nannoplankton are found mixed with middle Eocene planktonic foraminifers. At Atlantic City, Discoaster saipanensis ranges to the top of the Absecon Inlet Formation, indicating an age of Zone NP19/20 (Aubry in Miller et al., 1994a; Fig. 2). The base of the formation coincides with the first occurrence of Porticulasphaera semiinvoluta, indicating planktonic foraminiferal Zone P15 or younger. The highest occurrence of Turborotalia cerroazulensis pomeroli at $1295 \mathrm{ft}(394.7 \mathrm{~m})$ indicates a zonal assignment equivalent to the base of Zone P16 (Liu et al., Chapter 10, this volume). In the ACGS\#4 borehole, the highest occurrence of Discoaster saipanensis is associated with a disconformity at $695 \mathrm{ft}(211.8 \mathrm{~m})$. Because of the continuous occurrence of Hantkenina spp. between 695 and $624 \mathrm{ft}(211.8$ and $190.2 \mathrm{~m})$, the sediments at ACGS\#4 are assigned to the Eocene. Sediments between 624 and $615 \mathrm{ft}$ (190.2 and $187.5 \mathrm{~m}$ ) do not contain Hantkenina spp. (Poore and Bybell, 1988) and may be lowermost Oligocene; however, it is more likely that the absence of Hantkenina is caused by dissolution or environmental exclusion. The upper part of the section at ACGS\#4 is thus younger than the section at Atlantic City (Fig. 2).

Five Sr-isotopic age estimates obtained at the ACGS\#4 borehole between 695.7 and $624.5 \mathrm{ft}(212.0$ and $190.3 \mathrm{~m})$ by Miller et al. (1990) range from 34.8 to $33.3 \mathrm{Ma}$ (time scale of Berggren et al. [1995] using the regressions of Oslick et al. [1994]; Table 1). Two other samples measured at 750.0 and $731.5 \mathrm{ft}(228.6$ and $223.0 \mathrm{~m})$ are too old to be dated using Sr-isotopic stratigraphy (Table 1). At the Atlantic City borehole, a Sr-isotopic age estimate of $34.8 \mathrm{Ma}$ was obtained at $1204.1 \mathrm{ft}$ (367.0 m; Miller et al., 1994a). Two other samples collected at 1335.0 and $1301.1 \mathrm{ft}(406.9$ and $369.6 \mathrm{~m}$ ) are too old to be dated using Sr-isotopic stratigraphy (Table 1). These dates agree with a late Eocene age assignment, although large errors from samples of this age $( \pm 1.2$ m.y.) make it impossible to date the sections further with $\mathrm{Sr}$-isotopic stratigraphy.

\section{BENTHIC FORAMINIFERS}

Quantitative benthic foraminiferal studies were used to interpret the environments of deposition and to establish water depth fluctuations in the upper Eocene sediments from New Jersey. Fifty-five samples were examined and a total of 120 species were identified 


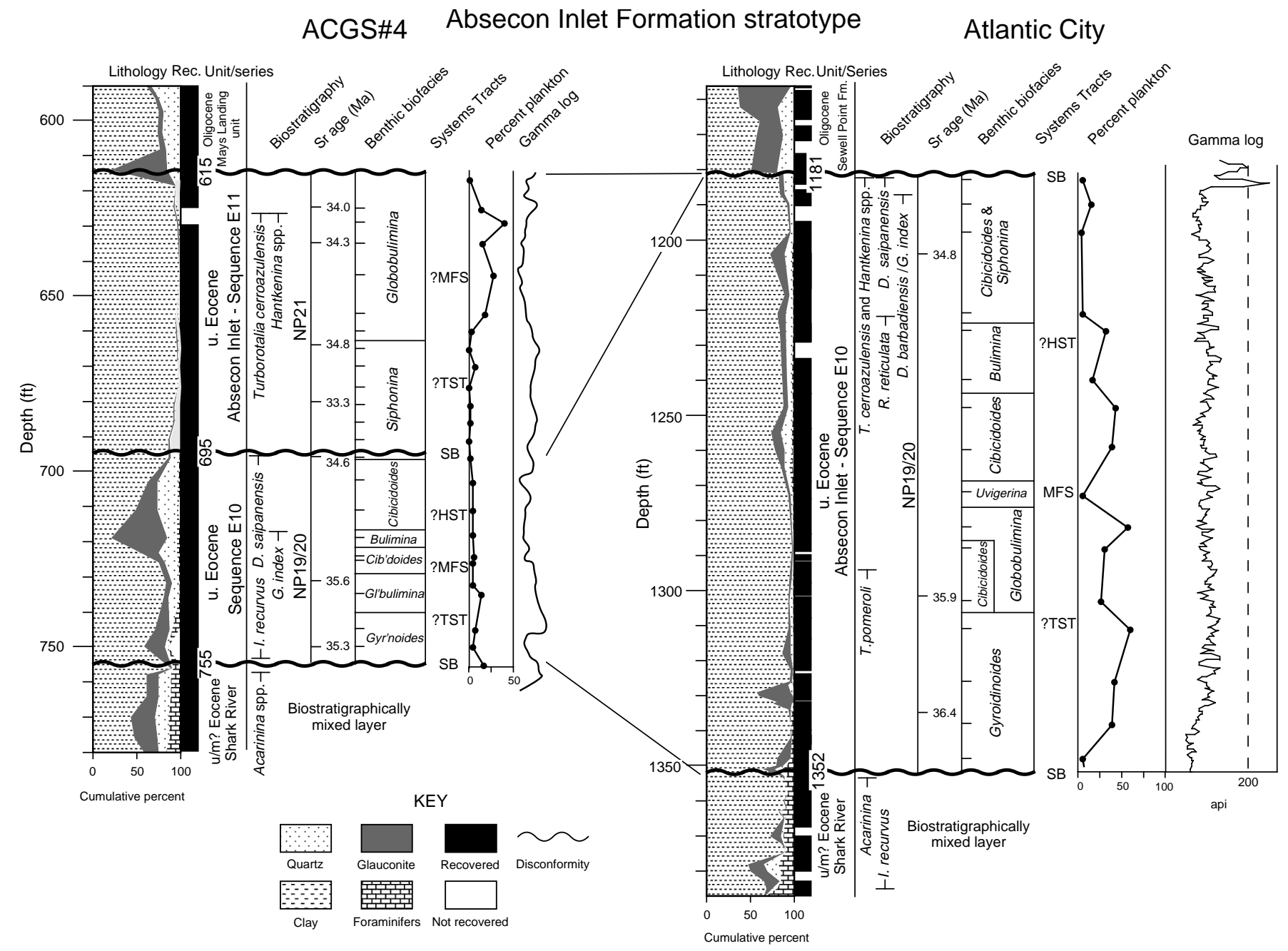

Figure 2. Composite lithologic column of the stratotypes for the Absecon Inlet Formation.

from approximately 21,586 specimens (see Browning [1996] for data file). Five factors were extracted explaining $78.7 \%$ of the faunal variation (Fig. 3; see Browning [1996] for factor analysis). These are arranged from shallower to deeper, based on the biofacies model developed below.

\section{Siphonina eocenica Biofacies}

This biofacies is represented by Factor 1, explaining $20.2 \%$ of the faunal variation (Fig. 4). It is strongly dominated by Siphonina eocenica (score $=9.9$ ). In addition, Hoeglundina elegans (score = 2.8), Cibicidoides speciosus (score $=2.6$ ), and Ceratobulimina eximia (score $=2.3$ ) are important components of the fauna. This factor is present in the ACGS\#4, Atlantic City, and Cape May boreholes at the top of calcareous nannoplankton Zone NP19/20 and the bottom of Zone NP21. In the modern ocean, Siphonina is known from both neritic and bathyal depths (van Morkhoven et al., 1986), but it was confined to neritic depths before the Oligocene (van Morkhoven et al., 1986). H. elegans is widespread in the modern Atlantic Ocean, with a depth range from 42 to $>4000 \mathrm{~m}$ (van Morkhoven et al., 1986). A Ceratobulimina-dominated fauna is found updip in a split-spoon sample from Medford, New Jersey. A Sr-isotopic age of 35.1 Ma was obtained for the Medford sample, indicating that it is similar in age to the Absecon Inlet Formation at the downdip boreholes. The sample contains abundant quartz sand, and the fauna was affected by dissolution. Nevertheless, the Medford borehole indicates that the abundance of Ceratobulimina increases updip within this sequence. The average percent planktonic foraminifers for samples belonging to this biofacies is $2.6 \%$. As a result of the very low percent of planktonic foraminifers and the dominance of $S$. eocenica and Ceratobulimina, this is presumed to be the shallowest biofacies recovered.

\section{Cibicidoides speciosus Biofacies}

This biofacies is represented by Factor 3, explaining $23.4 \%$ of the faunal variation (Fig. 5). It is dominated by Cibicidoides speciosus (score $=10.1$ ). In addition, Lenticulina cf. limbosus (score $=1.8), G y$ roidinoides octocameratus (score $=1.6$ ), and Cibicidoides cocoaensis (score $=1.6$ ) are components of the fauna. This fauna is also characterized by the absence of Siphonina eocenica (score $=-3.0$ ). The average percent of planktonic foraminifers for samples belonging to this biofacies is $18.2 \%$. This biofacies is the most common factor in Unit B (735-695 ft [224-212 m] at ACGS\#4) of Owens et al. (1988).

\section{Globobulimina ovata Biofacies}

This biofacies is represented by Factor 2, explaining $17.0 \%$ of the faunal variation (Fig. 6). It is dominated by Globobulimina ovata (score $=10.3$ ). In addition, Melonis barleeanum (score $=2.1$ ), Cerato- 
Table 1. Strontium age estimates for New Jersey Coastal Plain boreholes.

\begin{tabular}{lccccc}
\hline Location & $\begin{array}{c}\text { Depth } \\
(\mathrm{ft})\end{array}$ & $\begin{array}{c}\text { Depth } \\
(\mathrm{m})\end{array}$ & ${ }^{87} \mathrm{Sr} /{ }^{86} \mathrm{Sr}$ & $\begin{array}{c}\text { Precision } \\
( \pm)\end{array}$ & $\begin{array}{c}\text { Estimated } \\
\text { age } \\
(\mathrm{Ma})\end{array}$ \\
\hline ACGS\#4 & 624.5 & 190.3 & 0.707852 & 0.000014 & 34.0 \\
& 635.0 & 193.5 & 0.707840 & 0.000004 & 34.3 \\
& 664.5 & 202.5 & 0.707821 & 0.000007 & 34.8 \\
& 680.5 & 207.4 & 0.707879 & 0.000013 & 33.3 \\
& 695.7 & 212.0 & 0.707830 & 0.000005 & 34.6 \\
& 731.5 & 223.0 & 0.707793 & 0.000004 & 35.6 \\
Atlantic City & 750.0 & 228.6 & 0.707805 & 0.000005 & 35.3 \\
& 1204.1 & 367.0 & 0.707823 & 0.000013 & 34.8 \\
& 1301.1 & 396.6 & 0.707784 & 0.000013 & 35.9 \\
Medford & 1335.0 & 406.9 & 0.707763 & 0.000007 & 36.4 \\
& 162.2 & 49.4 & 0.707813 & 0.000008 & 35.1 \\
\hline
\end{tabular}

Note: Time scale of Berggren et al. (1995) is used throughout.

bulimina eximia $($ score $=1.9)$, and Oridorsalis umbonatus (score $=$ 1.6) are important components of the fauna. In the modern ocean, Globobulimina, an infaunal detritivore, is known in all environments from the shelf to bathyal depths (Murray, 1991). Melonis, also an infaunal detritivore in the modern ocean, ranges from neritic to bathyal depths (Murray, 1991). Factor 2 is found at the top of the Eocene at the ACGS\#4 borehole. It is present in the Atlantic City borehole, but is absent from the Cape May borehole. It is usually found in the finest grained sediments in the Absecon Inlet Formation and probably represents the deepest water fauna recovered. The average percent of planktonic foraminifers for samples belonging to this biofacies is $21.3 \%$.

\section{Gyroidinoides octocameratus Biofacies}

This biofacies is represented by Factor 5, which explains $9.5 \%$ of the faunal variation (Fig. 7). It is dominated by Gyroidinoides octocameratus (score $=6.5$ ) and Uvigerina multistriata $($ score $=6.1)$. In addition, Hanzawaia mauricensis (score $=3.9$ ) and Alabamina wilcoxensis (score $=3.0$ ) are important components of the fauna. This factor is dominant at the base of the Absecon Inlet Formation in the ACGS\#4 and Atlantic City boreholes. It is also important at Atlantic City and Cape May in the sediments below peak abundances in $\mathrm{Bu}$ limina jacksonensis (Factor 4). Christensen et al. (1995) noted that the upper Eocene at ACGS\#4 was dominated by U. multistriata and its distribution was characterized by peaks of occurrence, which they inferred were associated with flooding surfaces separating paraconformities. The current study does not corroborate this finding, perhaps because of the larger number of samples analyzed in the ACGS\#4 borehole and the fact that this study incorporates more than one borehole in the New Jersey Coastal Plain. U. multistriata is reported from shelf and upper bathyal sediments in association with clays, quartz, and glauconite (Boersma, 1984). Modern Hanzawaia spp. are epifaunal passive suspension feeders on the inner shelf. The average percent of planktonic foraminifers for samples belonging to Factor 5 is $28.0 \%$.

\section{Bulimina jacksonensis Biofacies}

This biofacies is represented by Factor 4, explaining $8.6 \%$ of the faunal variation (Fig. 8). It is dominated by Bulimina jacksonensis (score $=11.0)$. In addition, Lenticulina cf. limbosus $($ score =1.1) and Gyroidinoides octocameratus (score $=1.0$ ) are important components of the fauna. Overall, B. jacksonensis accounts for $48 \%$ of the total fauna. This fauna is found in all boreholes on the coastal plain at approximately the same level, near the top of Zone NP19/20. It is associated with the highest occurrence of Reticulofenestra reticulata (identified as Cribrocentrum reticulatum at ACGS\#4; Poore and Bybell, 1988). B. jacksonensis is a widely distributed upper Eocene benthic foraminifer and is found in middle neritic through upper bathyal sediments (van Morkhoven et al., 1986). A fauna dominated by the morphologically similar Bulimina alazanensis occurred on the New Jersey slope and other intermediate water depth locations in the Atlantic ocean (Katz and Miller, 1996). This intra-late Eocene event is expressed in the coastal plain by an apparently coeval Bulimina biofacies. The reason for the occurrence of this biofacies is not clear, although Katz and Miller (1996) speculate that it is related to paleoceanographic changes (e.g., low ventilation in intermediate waters). Based on the similar, correlative faunas, we assume that this paleoceanographic event is expressed on the coastal plain by the Bulimina biofacies and that this biofacies does not reflect water depth changes on the New Jersey Coastal Plain.

One sample at $1273 \mathrm{ft}(388.0 \mathrm{~m})$ in the Atlantic City borehole did not have high loadings for any of the factors extracted. This unusual assemblage was dominated by Uvigerina nuttalli $(>80 \%)$, an otherwise uncommon taxon in the Absecon Inlet Formation. Close sampling reveals that this $U$. nuttalli flood is $\sim 2 \mathrm{ft}(0.6 \mathrm{~m})$ thick in the Atlantic City borehole. This species usually occurs in relatively shallow-water carbonate-rich clays (Boersma, 1984).

\section{Depth Model}

These assemblages represent distinct groupings of foraminifers that inhabited discrete paleoenvironments on the continental shelf. Thus, they are biofacies with predictive value concerning the environments they inhabited. Because of the limited number of boreholes present and the lack of detailed age control in these sediments (i.e., better than 0.5-1.0 m.y. resolution), it is not possible to rigorously calibrate a paleoslope model using the techniques of Olsson and Nyong (1984), or to interpret the preferred depths for these biofacies. For example, the Cape May borehole recovered only approximately one-half of the formation, and differences in the timing of biofacies changes between the ACGS\#4 and Atlantic City boreholes are difficult to resolve (Fig. 9).

Using the microfauna found at Medford, New Jersey, and assuming that it represents water depths of $\sim 30$ m (based upon the high percentage of quartz sand and very low planktonic foraminiferal abundances), it is possible to crudely assign paleodepths to the faunas considered here. As noted earlier, the Siphonina eocenica biofacies appears to be the shallowest water biofacies, followed by the Cibicidoides speciosus biofacies and the Globobulimina ovata biofacies. The Gyroidinoides octocameratus biofacies is found only at the base of the sections in association with glauconite, and most likely is confined to the transgressive systems tracts, whereas the Bulimina jacksonensis fauna may be related to a paleoceanographic event unrelated to water depth changes. The Medford sample is $70 \mathrm{~km}$ updip from Atlantic City. Assuming that the upper Eocene paleoshelf had a gradient similar to that of the modern shelf $(1: 1000)$, there was $\sim 70$-m water depth difference between the two sites. Because the Cibicidoides speciosus biofacies is the most common biofacies at Atlantic City, it is reasonable to assume that it is the downdip equivalent of the assemblage in the Medford sample and that it thus has a paleodepth of $100 \pm 30 \mathrm{~m}$. The updip Siphonina biofacies is assigned a paleodepth of $75 \pm 25 \mathrm{~m}$, and the downdip Globobulimina biofacies is assigned a paleodepth of $125 \pm 25 \mathrm{~m}$. Biofacies 5 is difficult to assign to a specific water depth, but is inferred to be from depths similar to those of Biofacies 2. This biofacies is restricted to the transgressive systems tracts. Overlap between these water depth estimates represents the uncertainties involved.

Based upon the depth zonation derived for the biofacies defined, we derived a chart showing the preferred depth habitat for the species identified in this study (Fig. 10). Following the example of Olsson and Nyong (1984), these distributions are based upon the percent occurrence of each species in the different biofacies arranged according to depth. The figure represents a composite of all of those samples belonging to the same biofacies. Species whose occurrences are less than $1 \%$ in all biofacies have been excluded from this chart because 

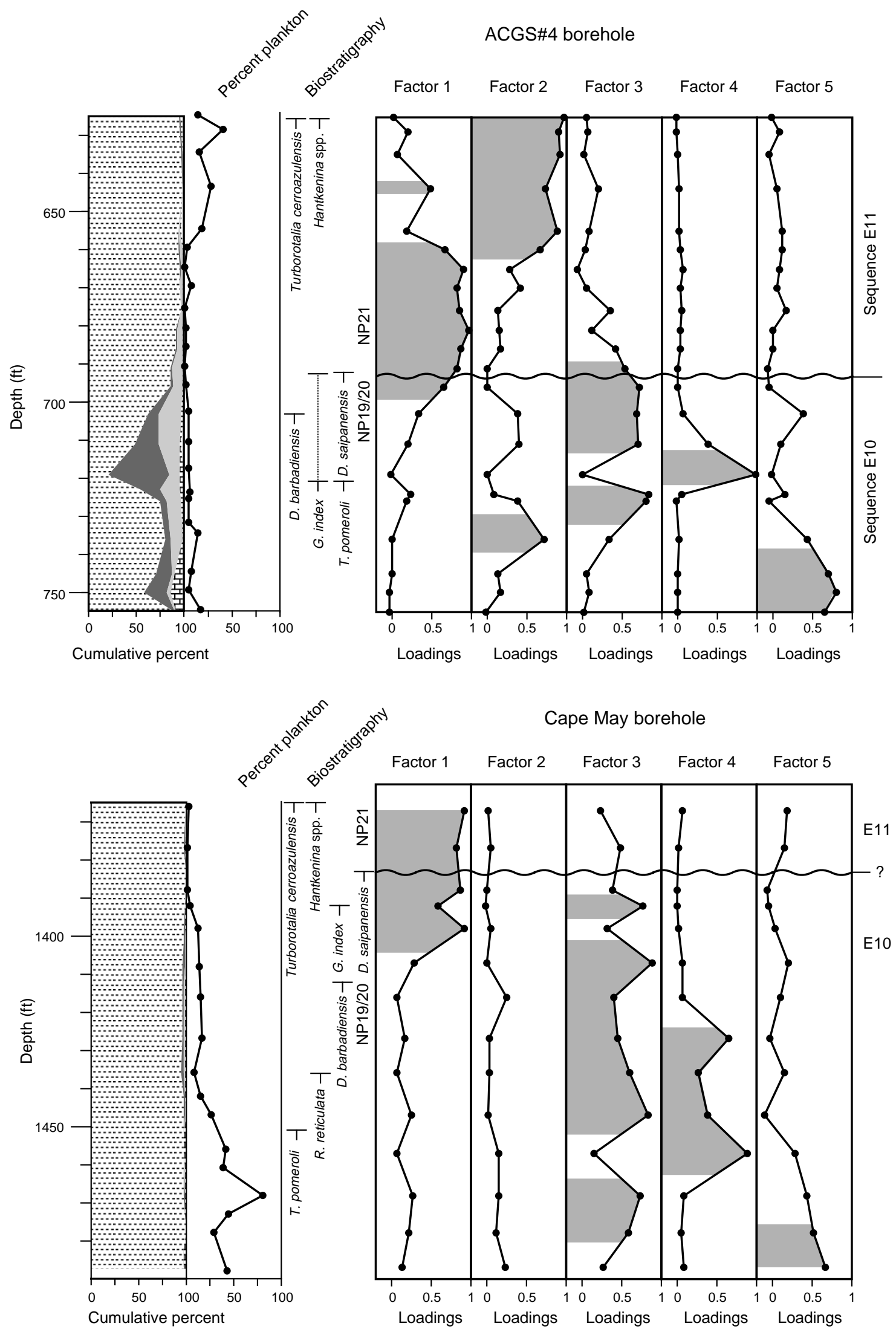

Figure 3. Distribution of upper Eocene benthic foraminiferal factors found on the New Jersey Coastal Plain. Shaded areas represent sediments where a particular factor is significant. 


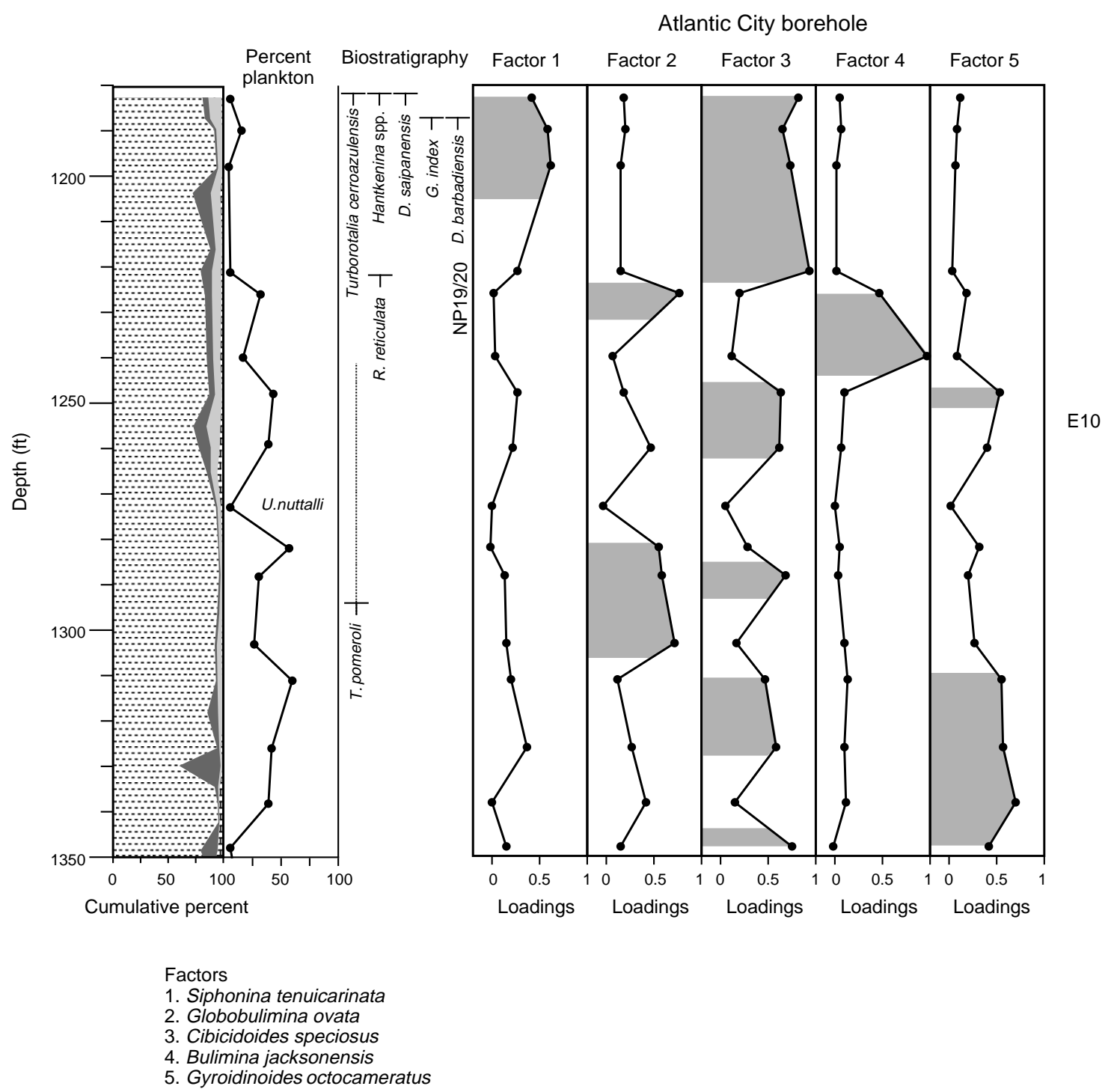

Figure 3 (continued).

they are too rare for meaningful generalizations to be drawn about their preferred depth habitat.

\section{DISCUSSION}

The Absecon Inlet Formation consists of marine sediments deposited in middle to outer neritic paleowater depths (between 30 and 150 $\mathrm{m})$. To understand the patterns of deposition, an attempt was made to identify and date sequence boundaries and to tie the facies within sequences to specific systems tracts (Posamentier et al., 1988).

\section{Sequence E10}

Eocene Sequence E10 is found in all boreholes (ACGS\#4 between 755 and $695 \mathrm{ft}$ [ 230.1 and $211.8 \mathrm{~m}$ ], Island Beach between 752 and $710 \mathrm{ft}$ [229.2 and $216.4 \mathrm{~m}$ ], Atlantic City between 1352 and 1183 $\mathrm{ft}$ [412.1 and $360.6 \mathrm{~m}$ ], and Cape May between 1500 and $1360 \mathrm{ft}$ [457.2 and $414.5 \mathrm{~m}$ ]; Fig. 11). The base of this sequence was not penetrated at Cape May. A split-spoon sample from this sequence was recovered at $161 \mathrm{ft}(49.1 \mathrm{~m})$ at Medford. This sequence is assigned to calcareous nannoplankton Zone NP19/20 and planktonic foramin- iferal Zone P16 (Miller et al., 1994a, 1994b; Liu et al. Chapter 10, this volume; Poore and Bybell, 1988). The base of this sequence is generally a sharp surface, separating black clays with an abundant microfauna below from gray clays above. At Island Beach, the surface is marked by an abrupt change from clayey medium to coarse quartz sands below (Toms River Member of the Shark River Formation) to fine to very fine sandy clays. This surface is associated with the highest occurrence of acarininids, truncorotalids, morozovellids, and other middle Eocene planktonic foraminifers (Browning et al., Chapter 16 , this volume), which are interpreted as reworked.

All boreholes exhibit a similar succession of lithofacies and biofacies within this sequence (Fig. 11). In all boreholes, the amount of glauconite sand increases in the sediments above the black clays. At Atlantic City, these glauconite sands, which are dominated by the $G y$ roidinoides biofacies $(125 \pm 25 \mathrm{~m})$, extend to $\sim 1310 \mathrm{ft}(399.3 \mathrm{~m})$. The percent of planktonic foraminifers is generally highest in this unit, which is interpreted as the TST. Above this, the sediments are dominated by clay with less sand. They are dominated by Biofacies 2 (Globobulimina ovata, $125 \pm 25 \mathrm{~m}$ ). A flood of Uvigerina nuttalli occurs at $1273 \mathrm{ft}(388.0 \mathrm{~m})$ in the Atlantic City borehole. The $U$. nuttalli flood is interpreted as the MFS. Above $1273 \mathrm{ft}(388.0 \mathrm{~m})$ the amount of fine to very fine quartz and glauconite sand in the sediments in- 

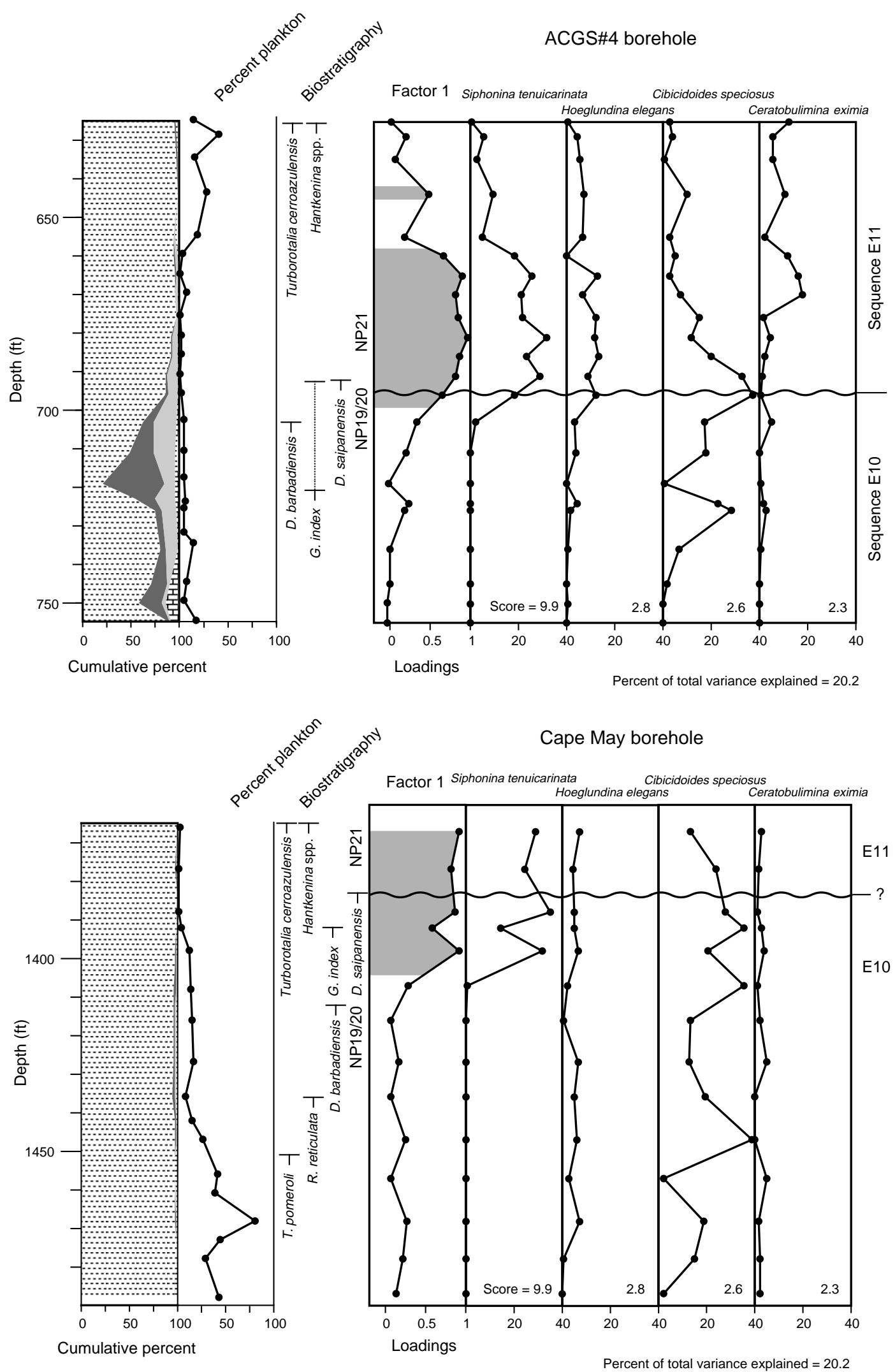

Figure 4. Species graph for Factor 1 (Siphonina biofacies) and related species. Distribution of species with high loadings are graphed (percent of the total sample). 


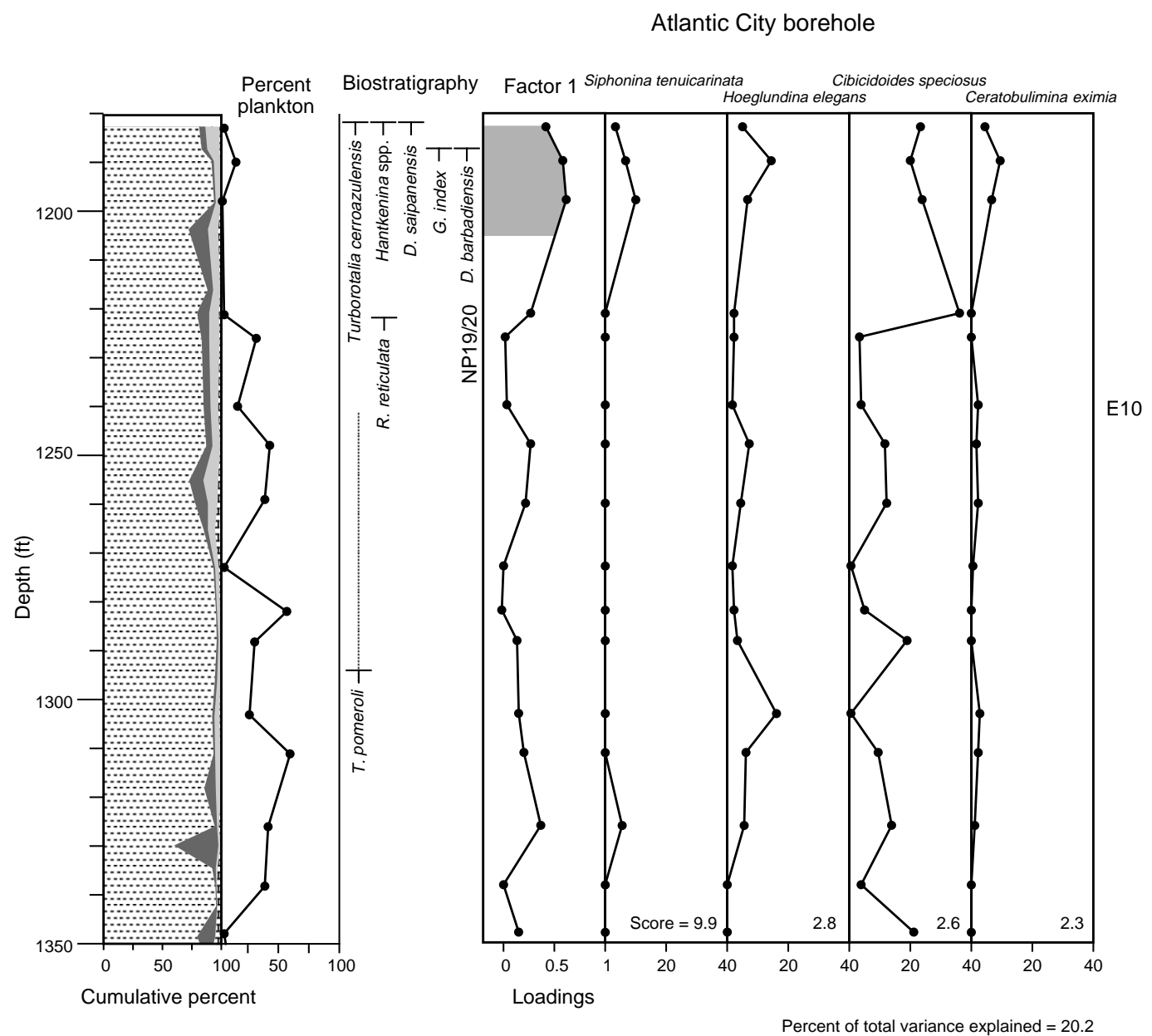

Figure 4 (continued).

creases. These sediments are generally dominated by the Cibicidoides speciosus biofacies $(100 \pm 30 \mathrm{~m})$. At the top of this sequence $(1200 \mathrm{ft}[365.8 \mathrm{~m}]$ at Atlantic City), the Siphonina eocenica biofacies $(75 \pm 25 \mathrm{~m})$ becomes dominant. These sandier facies are interpreted as the regressive HST.

At the ACGS\#4 borehole, Owens et al. (1988) divided this unit into two parts based upon the presence of a surface at $735 \mathrm{ft}(224.0$ $\mathrm{m})$ in the borehole. This surface, and a similar one at Atlantic City at $1333 \mathrm{ft}(406.3 \mathrm{~m})$, are found within the transgressive systems tract as interpreted here. The significance of these surfaces is not certain. A coarse glauconite sand at $719 \mathrm{ft}$ at ACGS\#4 contains two-colored glauconite, which is assumed to be recycled (see Owens et al. [Chapter 2 , this volume] for discussion of recycled glauconite).

\section{Sequence E11}

A second sequence (E11), with a more limited occurrence, is found at ACGS\#4 between 695 and $615 \mathrm{ft}(211.8$ and $187.5 \mathrm{~m})$ and at Island Beach between 710 and $698 \mathrm{ft}$ (216.4 and $212.8 \mathrm{~m}$; Fig. 11). The base of this sequence may occur at Cape May at $1383 \mathrm{ft}(421.5$ $\mathrm{m})$. The sequence is absent at Atlantic City. The basal contact at ACGS\#4, as described by Owens et al. (1988) at $695 \mathrm{ft}(211.8 \mathrm{~m})$, separates an olive-black, medium glauconite quartz sand below from a brownish black, very clayey silt containing more glauconite than the beds above. This also approximates the boundary between calcareous nannoplankton Zones NP19/20 and NP21. According to Poore and Bybell (1988), the highest occurrence of Discoaster saipanensis is at $694 \mathrm{ft}(211.5 \mathrm{~m})$. At ACGS\#4, Eocene planktonic foraminifers such as the Turborotalia cerroazulensis lineage and Hantkenina in- dicate uppermost Zone P16 or Zone P17. The highest occurrence of D. saipanensis at Island Beach, at $710 \mathrm{ft}(216.4 \mathrm{~m}$; Miller et al., 1994b), is similarly associated with a disconformable surface and an increase in glauconite. Hantkenina is found in the Island Beach core to $698 \mathrm{ft}$ (212.8 m). At Cape May, there is no physical surface associated with the highest occurrence of $D$. saipanensis at $1383 \mathrm{ft}(421.5$ $\mathrm{m})$. Because of the continued occurrence of Eocene planktonic foraminifers in the section between 1383 and $1360 \mathrm{ft}$ (421.5 and 414.5 $\mathrm{m})$, this section may be correlative with Sequence E11.

Sequence E11 is thickest at the ACGS\#4 borehole. The sediments within this sequence are very fine grained. The percent of sand at the base of the sequence is $\sim 8 \%$, and at the top it decreases to $2 \%$. The benthic foraminiferal biofacies change from the Siphonina biofacies at the base to the Globobulimina biofacies at the top. The percent planktonic foraminifers in the sequence increases from $0 \%$ to $6 \%$ at the base and from $15 \%$ to $40 \%$ at the top. A rapid deepening is indicated by an increase in percent planktonic foraminifers, a decrease in grain size, and the overstepping of biofacies (i.e., a change from the Siphonina biofacies [ $75 \pm 25 \mathrm{~m}$ ] to the Globobulimina biofacies [125 $\pm 25 \mathrm{~m}$ ] without the Cibicidoides speciosus biofacies in between [100 $\pm 30 \mathrm{~m}]$ ). Thus, the sequence preserved is interpreted as TST truncated on top by a disconformity separating the Absecon Inlet Formation from the glauconitic and coarser grained Oligocene Mays Landing unit (Owens et al., 1988; Christensen et al., 1995).

Integrated stratigraphy yields approximate dates for MFS and sequence boundaries and estimates for the duration of the associated unconformities from the New Jersey upper Eocene. Precise dating of the New Jersey Coastal Plain upper Eocene sequences was not possible because of the difficulty in identifying time-significant bio- 

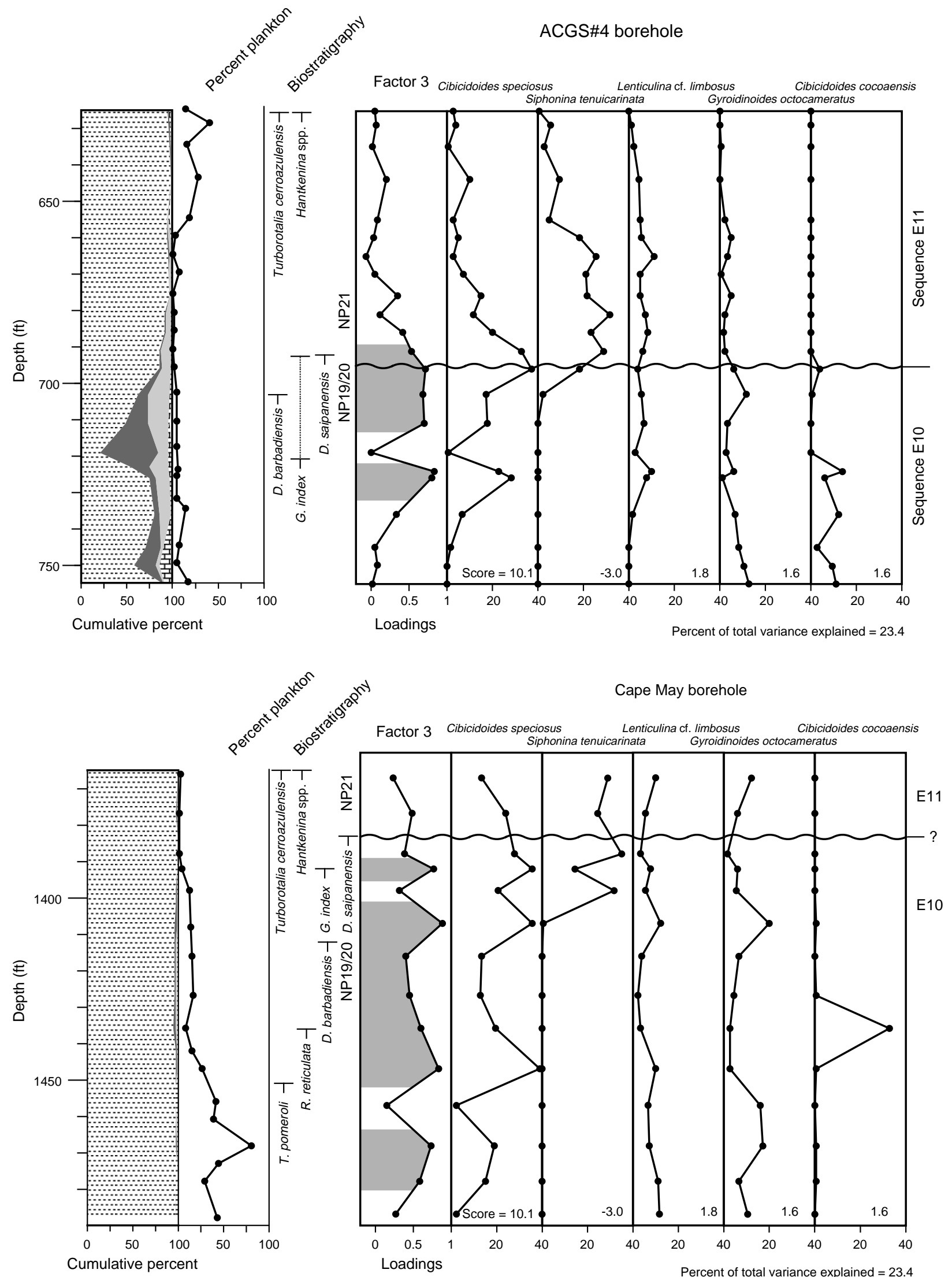

Figure 5. Species graph for Factor 3 (Cibicidoides biofacies) and related species. Distribution of species with high loadings are graphed (percent of the total sample). 


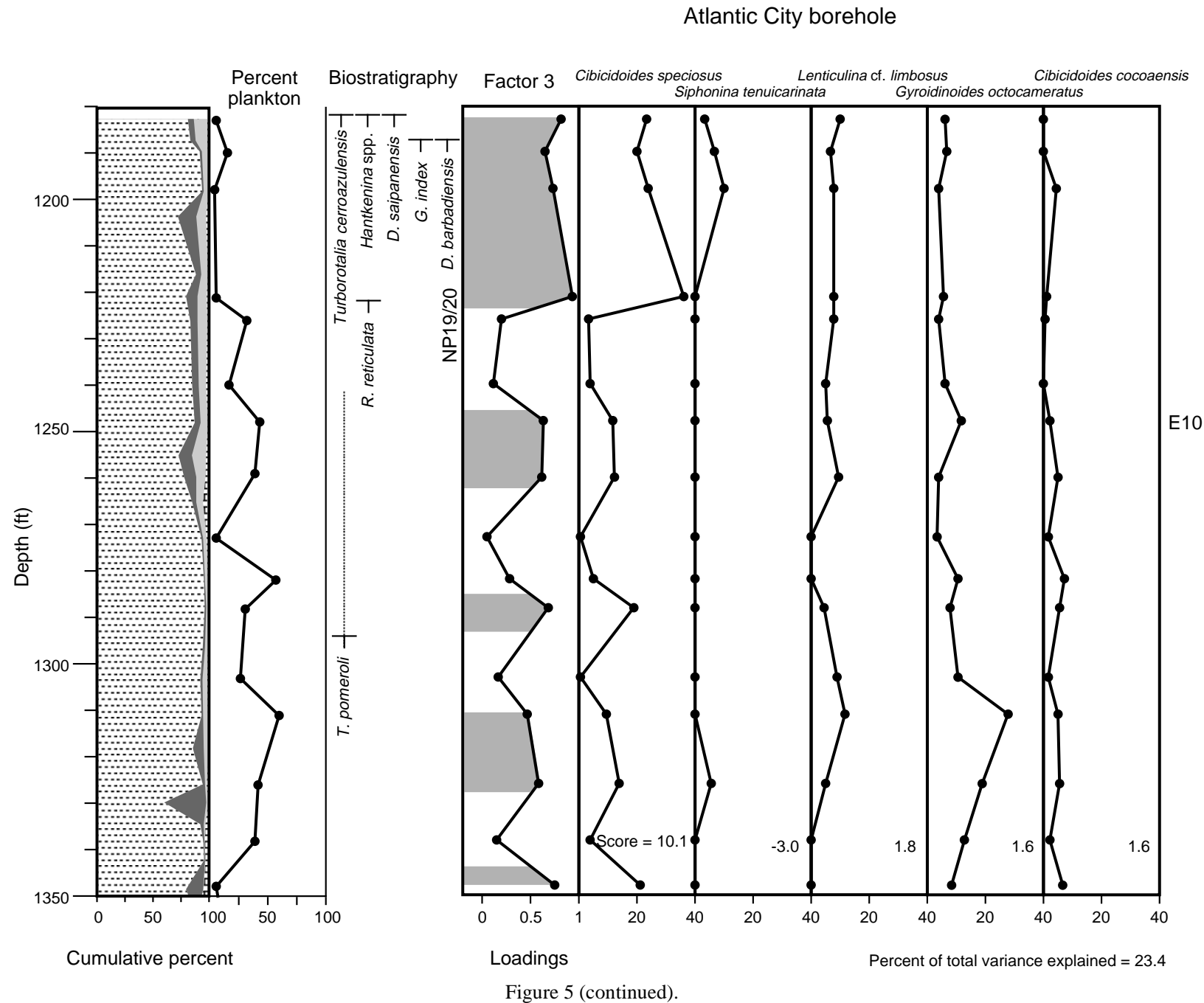

stratigraphic events in these mid-latitude, neritic sediments. Based on the occurrence of Isthmolithus recurvus, the base of Sequence E10 is no older than $36 \mathrm{Ma}$, and based on the occurrence of Turborotalia cerroazulensis pomeroli, it is no younger than $35.3 \mathrm{Ma}$ (Fig. 12). The highest occurrence of Reticulofenestra reticulata consistently occurs in the middle of this sequence, stratigraphically below the highest occurrences of Discoaster barbadiensis and Globigerapsis index, which are consistently found at the top of this sequence. This places the top of the sequence between 35 and 34.3 Ma. Magnetostratigraphic studies of the Absecon Inlet Formation at ACGS\#4 (Miller et al., 1990) and Atlantic City (Van Fossen, Chapter 22, this volume) show are predominantly normal polarity compared with the GPTS, which shows predominantly reversed polarity (Figs. 12, 13). This is attributed to normal overprinting, and magnetostratigraphy offers little assistance in dating these sediments. An age-depth plot integrating time significant events for the Atlantic City borehole (Fig. 12) favors placing the base of this sequence at $35.5 \mathrm{Ma}$ and the top at 34.8 $\mathrm{Ma}$, assuming a constant sedimentation rate. This yields an approximate sedimentation rate of $74 \mathrm{~m} / \mathrm{m} . \mathrm{y}$. for Sequence E10. The age of the MFS, equivalent to the Uvigerina nuttalli flood, is 35.2 Ma.

Sequence E11 was deposited in the latest Eocene between the last occurrence of $D$. saipanensis (34.2 Ma) and the last occurrence of Hantkenina (33.8 Ma). More precise dates are not available at this time (Fig. 12). The duration of the unconformity separating Sequences E10 and E11 is $~ 0.6$ m.y. The sedimentation rate for Sequence E11 is on the order of $60 \mathrm{~m} / \mathrm{m}$.y. The MFS for Sequence E11 is not clearly defined. The hiatus represented by the unconformity separating the Absecon Inlet Formation from the overlying Oligocene Sewell Point Formation is $\sim 1$ m.y. (Pekar et al., Chapter 15, this volume).

We compare the record of sea-level change from the New Jersey upper Eocene to the record of third-order sea-level events developed by Haq et al. (1987) and the global deep-sea $\delta^{18} \mathrm{O}$ record ( $\mathrm{Za}-$ chos et al., 1996; Fig. 13). We recalibrated the Haq et al. (1987) record to the Berggren et al. (1995) time scale using the magnetostratigraphy and biostratigraphy provided in the "cycle chart." The record of Haq et al. (1987) contains three upper Eocene sequences with the bases of the sequences dated at 37.0 Ma (base of TA4.1), 35.7 Ma (base of TA4.2), and 34.3 Ma (base of TA4.3), whereas a fourth at 33.6 Ma (base of TA4.4) marks the Eocene/Oligocene boundary. The record of deposition from New Jersey is in agreement with the Haq et al. (1987) record, because the base of Sequence E10 ( 35.7 Ma) corresponds to the base of TA4.2 (37 Ma), the base of Sequence E11 ( $34.1 \mathrm{Ma})$ corresponds to the base of TA4.3 (34.3 Ma), and the top of Sequence E11 ( 33.8 Ma) corresponds to the base of TA4.4 (33.6 Ma).

To understand the causes of the sequence boundaries found in the upper Eocene, we compare the record of sedimentation to the global $\delta^{18} \mathrm{O}$ (Fig. 12). A high-resolution benthic foraminiferal $\delta^{18} \mathrm{O}$ record for the late Eocene/early Oligocene transition has recently been published (Zachos et al., 1996). Similar high-resolution, low-latitude, planktonic $\delta^{18} \mathrm{O}$ records do not yet exist, and covariance cannot be used to infer ice-volume changes. Comparison of the benthic $\delta^{18} \mathrm{O}$ 

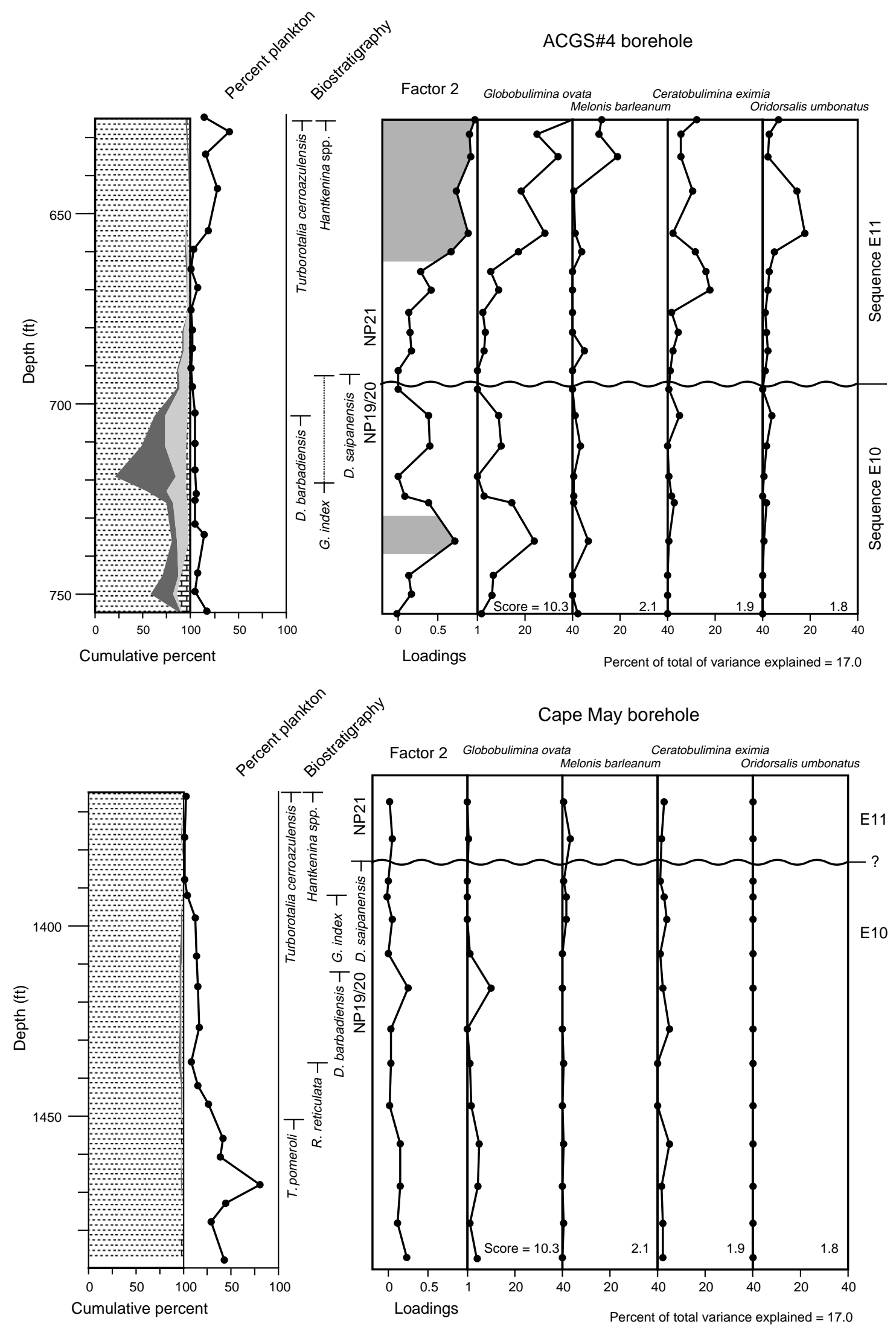

Figure 6. Species graph for Factor 2 (Globobulimina biofacies) and related species. Distribution of species with high loadings are graphed (percent of the total sample). 


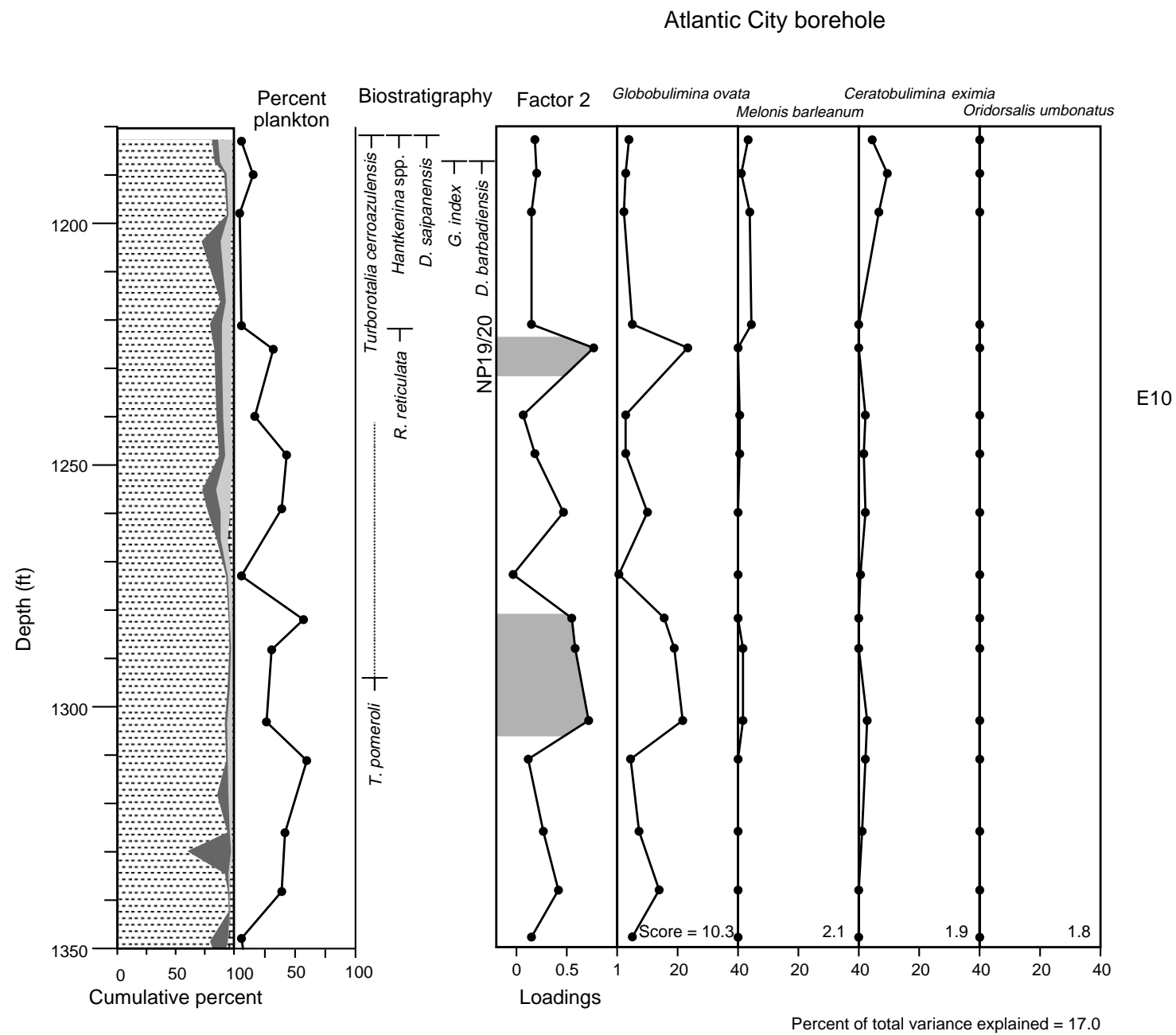

Figure 6 (continued).

records with the New Jersey upper Eocene shows that the major unconformity separating Sequence E11 from Oligocene sediments correlates well with the major $\delta^{18} \mathrm{O}$ increase that takes place in the earliest Oligocene (the increase associated with Zone Oil of Miller et al., 1991). The unconformity between Sequences E10 and E11 occurred before the major increase began. Hole $522 \mathrm{~A}$ contains a $\delta^{18} \mathrm{O}$ increase that correlates approximately with the E10/E11 sequence boundary (Fig. 13). The data may indicate that the cooling and growth of ice at the end of the Eocene consisted of a two-step event, a smaller event at 34.2 Ma that created small unconformities on the shelf, and a larger cooling and ice build up that separates Eocene and Oligocene strata. Thus, late Eocene sequence boundaries appear to correlate with inferred glacioeustatic lowerings, as they do in the Oligocene to Miocene (Miller et al., 1996b). However, we caution that chronologic resolution in the upper Eocene of these boreholes (0.5-1.0 m.y.) is not refined enough and that the $\delta^{18} \mathrm{O}$ record of this interval is not known well enough to establish an unequivocal link.

\section{CONCLUSION}

Upper Eocene sediments are currently known from five boreholes on the New Jersey Coastal Plain. These glauconitic, clayey sediments are here named the Absecon Inlet Formation. Upper Eocene sediments consist of clays and silts with thin glauconitic sand beds. This upper Eocene silty clay is lithologically distinct from the overlying Oligocene sands and underlying middle Eocene quartz and glauconite sands. These sediments were deposited as two sequences, one in planktonic foraminiferal Zones P15-16 and calcareous nannoplankton Zone NP 19/20, and the second in Zones P16-17 and Zone NP21. Benthic foraminiferal biofacies analysis reveals that paleowater depths at the sites considered ranged from 75 to $125 \mathrm{~m}$. The timing of the unconformities bounding the two sequences comprising the Absecon Inlet Formation agrees with the Haq et al. (1987) eustatic record and with the global $\delta^{18} \mathrm{O}$ record.

\section{ACKNOWLEDGMENTS}

We thank S. Pekar and P. Sugarman for discussions, and M. Leckie, G. Jones, G. McGhee, D. Poore, R. Olsson, and S. Snyder for reviews. This study was supported by National Science Foundation Grants EAR92-18210 and EAR94-17108. This is Lamont Doherty Earth Observatory contribution 5698.

\section{REFERENCES}

Bandy, O.L., 1949. Eocene and Oligocene foraminifera from Little Stave Creek, Clarke County, Alabama. Bull. Am. Paleontol., 32:1-210.

Barron, J., Larsen, B., and Baldauf, J.G., 1991. Evidence for late Eocene to early Oligocene Antarctic glaciation and observations on late Neogene 

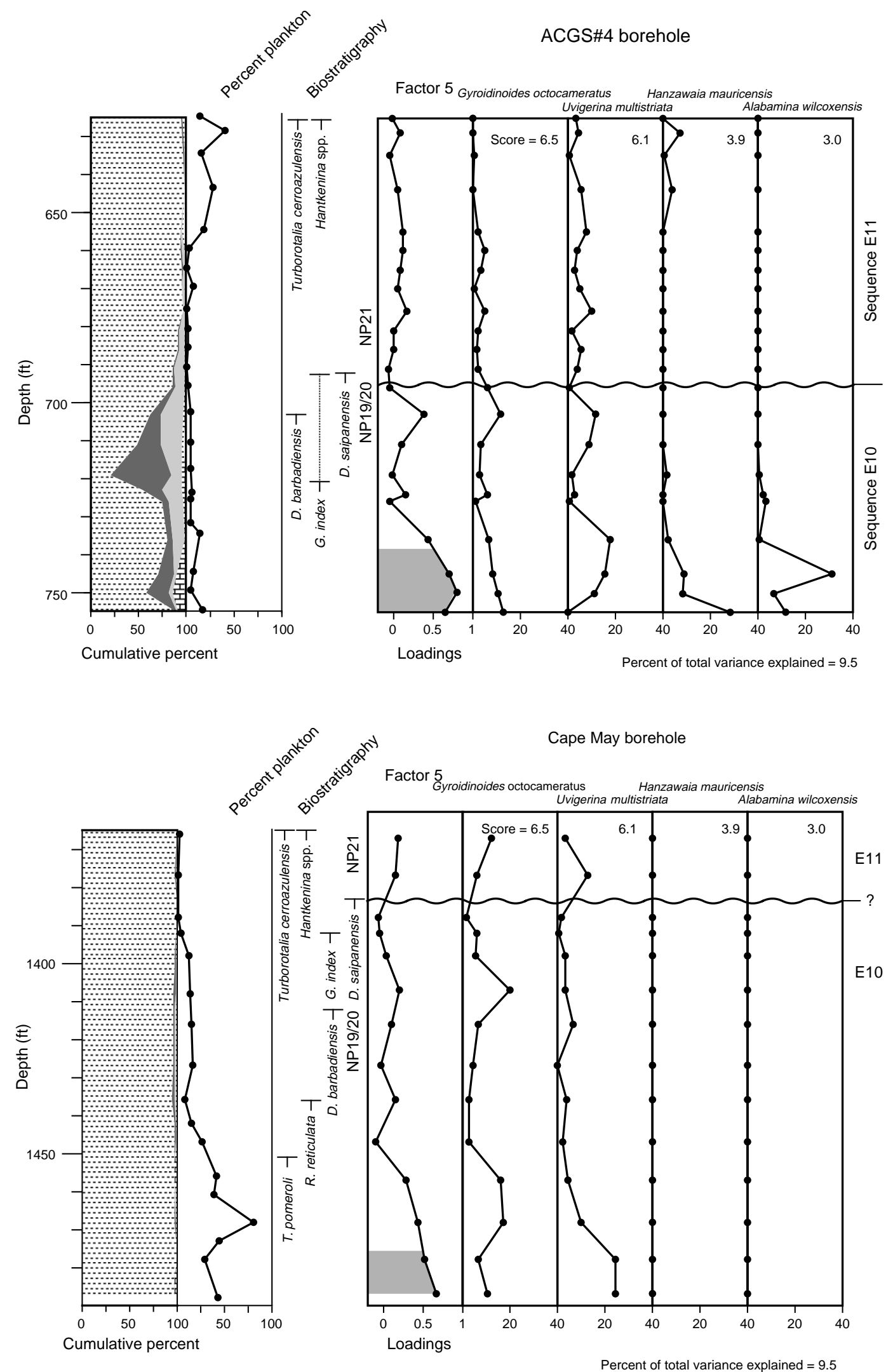

Figure 7. Species graph for Factor 5 (Gyroidinoides biofacies) and related species. Distribution of species with high loadings are graphed (percent of the total sample). 


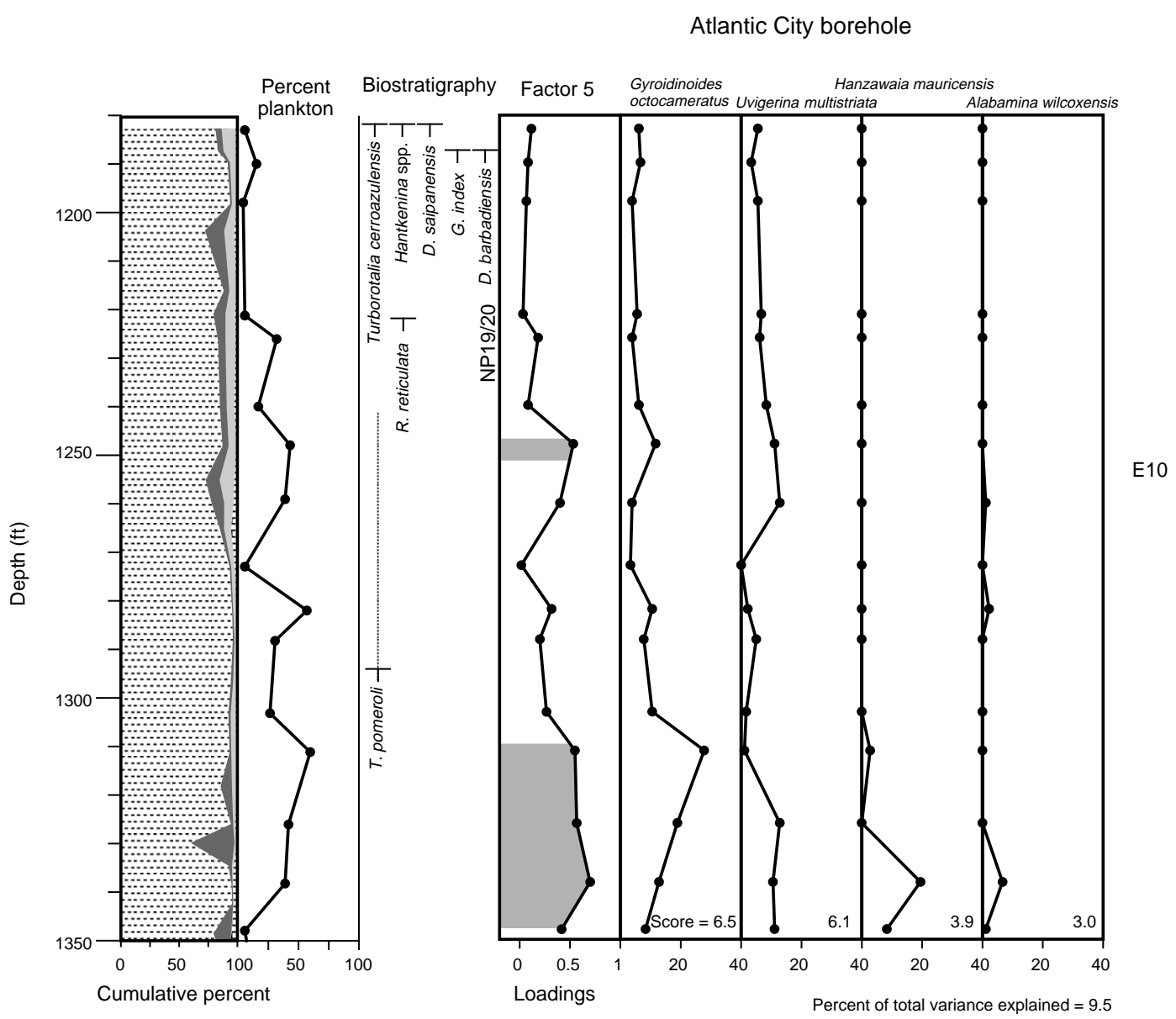

Figure 7 (continued).

glacial history of Antarctica: results from Leg 119. In Barron, J., Larsen, B., et al., Proc. ODP, Sci. Results, 119: College Station, TX (Ocean Drilling Program), 869-891.

Berggren, W.A., Kent, D.V., Swisher, C.C., III, and Aubry, M.-P., 1995. A revised Cenozoic geochronology and chronostratigraphy. In Berggren, W.A., Kent, D.V., Aubry, M.-P., and Hardenbol, J. (Eds.), Geochronology, Time Scales and Global Stratigraphic Correlation. Spec. Publ.Soc. Econ. Paleontol. Mineral., 54:129-212.

Boersma, A., 1984. A Handbook of Common Tertiary Uvigerina: Stony Point, NY (Microclimates Press).

Brown, P.M., Miller, J.A., and Swain, F.M., 1972. Structural and stratigraphic framework, and spatial distribution of permeability of the Atlantic Coastal Plain, North Carolina to New York. Geol. Surv. Prof. Pap. U.S., 796:1-79.

Browning, J.V., 1996. Eocene sequences and benthic foraminiferal biofacies on the New Jersey coastal plain [Ph.D. dissert.]. Rutgers University, New Brunswick, NJ.

Charletta, A.C., 1980. Eocene benthic foraminiferal paleoecology and paleobathymetry of the New Jersey continental margin [Ph.D. dissert.]. Rutgers University, New Brunswick, NJ.

Christensen, B.A., Miller, K.G., and Olsson, R.K., 1995. Eocene-Oligocene benthic foraminiferal biofacies and depositional sequence at the ACGS\#4 borehole, New Jersey coastal plain. Palaios, 10:103-132.

Christie-Blick, N., and Driscoll, N.W., 1995. Sequence stratigraphy. Ann. Rev. Earth Planet. Sci., 23:451-478.

Christie-Blick, N., Mountain, G.S., and Miller, K.G., 1990. Stratigraphic and seismic stratigraphic record of sea-level change. In Revelle, R.R. (Ed.), Sea-level Change: Washington (National Academy Press), 116-140.

Enright, R., 1969. The stratigraphy, micropaleontology, and paleoenvironmental analysis of the Eocene sediments of the New Jersey coastal plain [Ph.D. dissert.]. Rutgers University, New Brunswick, NJ.

Haq, B.U., Hardenbol, J., and Vail, P.R., 1987. Chronology of fluctuating sea levels since the Triassic. Science, 235:1156-1167.
Jones, G.D., 1983. Foraminiferal biostratigraphy and depositional history of the Middle Eocene rocks of the coastal plain of North Carolina. North Carolina Geol. Surv. Spec. Publ., 8.

Katz, M.E., and Miller, K.G., 1996. Eocene to Miocene oceanographic and provenance changes in a sequence stratigraphic framework: benthic foraminifers of the New Jersey Margin. In Mountain, G.S., Miller, K.G., Blum, P., Poag, C.W., and Twichell, D.C. (Eds.), Proc. ODP, Sci. Results, 150: College Station, TX (Ocean Drilling Program), 65-95.

Loutit, T.S., Hardenbol, J., Vail, P.R. and Baum, G.R., 1988. Condensed sections: the key to age determination and correlation of continental margin sequences. In Wilgus, C.K., Hastings, B.S., Ross, C.A., Posamentier, H.W., Van Wagoner, J., and Kendall, C.G.St.C. (Eds.), Sea-Level Changes: An Integrated Approach. Spec. Publ.-Soc. Econ. Paleontol. Mineral., 42:183-213.

Miller, K.G., et al., 1996a. Proc. ODP, Init. Repts., 150X (Suppl.): College Station, TX (Ocean Drilling Program).

Miller, K.G., Browning, J.V., Liu, C., Sugarman, P., Kent, D.V., Van Fossen, M., Queen, D., Goss, M., Gwynn, D., Mullikin, L., Feigenson, M.D., Aubry, M.-P., and Burckle, L.D., 1994a. Atlantic City site report. In Miller, K.G., et al., Proc. ODP, Init. Repts., 150X: College Station, TX (Ocean Drilling Program), 35-55.

Miller, K.G., Kent, D.V., Brower, A.N., Bybell, L.M., Feigenson, M.D., Olsson, R.K., and Poore, R.Z., 1990. Eocene-Oligocene sea-level changes on the New Jersey coastal plain linked to the deep-sea record. Geol. Soc. Am. Bull., 102:331-339.

Miller, K.G., and Lohmann, G.P., 1982. Environmental distribution of Recent benthic foraminifera on the northeast United States continental slope. Geol. Soc. Am. Bull., 93:200-206.

Miller, K.G., Mountain, G.S., Blum, P., Gartner, S., Alm Per, G., Aubry, M.P., Burckle, L.H., Guerin, G., Katz, M.E., Christensen, B.A., Compton, J., Damuth, J.E., Deconinck, J.F., de Verteuil, L., Fulthorpe, C.S., Hesselbo, S.P., Hoppie, B.W., Kotake, N., Lorenzo, J.M., McCracken, S., McHugh, C.M., Quayle, W.C., Saito, Y., Snyder, S.W., ten Kate, W.G., Urbat, M., 
Van Fossen, M.C., Vecsei, A., Sugarman, P.J., Mullikin, L., Pekar, S., Browning, J.V., Liu, C., Feigenson, M.D., Goss, M., Gwynn, D., Queen, D.G., Powars, D.S., Heibel, T.D., and Bukry, D., 1996b. Drilling and dating New Jersey Oligocene-Miocene sequences: ice volume, global sea level, and Exxon records. Science, 271:1092-1094.

Miller, K.G., Sugarman, P., Van Fossen, M., Liu, C., Browning, J.V., Queen, D., Aubry, M.-P., Burckle, L.D., Goss, M., and Bukry, D., 1994b. Island Beach site report. In Miller, K.G., et al., Proc. ODP, Init. Repts., 150X: College Station, TX (Ocean Drilling Program), 5-33.

Miller, K.G., Wright, J.D., and Fairbanks, R.G., 1991. Unlocking the Ice House: Oligocene-Miocene oxygen isotopes, eustasy, and margin erosion. J. Geophys. Res., 96:6829-6848.

Murray, J.W., 1991. Ecology and Palaeoecology of Benthic Foraminifera: London (Longman).

Olsson, R.K., Miller, K.G., and Ungrady, T.E., 1980. Late Oligocene transgression of middle Atlantic coastal plain. Geology, 8:549-554.

Olsson, R.K., and Nyong, E.E., 1984. A paleoslope model for CampanianLower Maestrichtian foraminifera of New Jersey and Delaware. J. Foraminiferal Res., 14:50-68.

Oslick, J.S., Miller, K.G., Feigenson, M.D., and Wright, J.D., 1994. Oligocene-Miocene strontium isotopes: stratigraphic revisions and correlations to an inferred glacioeustatic record. Paleoceanography, 9:427-443.

Owens, J.P., Bybell, L.M., Paulachok, G., Ager, T.A., Gonzalez, V.M., and Sugarman, P.J., 1988. Stratigraphy of the Tertiary sediments in a $945-$ foot-deep core hole near Mays Landing in the southeastern New Jersey Coastal Plain. Geol. Surv. Prof. Pap. U.S., 1484.

Poag, C.W., 1985. Depositional history and stratigraphic reference section for central Baltimore Canyon trough. In Poag, C.W. (Ed.), Geologic Evolution of the United States Atlantic Margin: New York (Van Nostrand Reinhold), 217-263.

Poag, C.W., Powars, D.S., Poppe, L.J., Mixon, R.B., Edwards, L.E., Folger, D.W., and Bruce, S., 1992. Deep Sea Drilling Project Site 612 bolide event: new evidence of a late Eocene impact-wave deposit and a possible impact site, U.S. east coast. Geology, 20:771-774.

Poore, R.Z., and Bybell, L.M., 1988. Eocene to Miocene biostratigraphy of New Jersey core ACGS \#4: Implications for regional stratigraphy. Geol. Surv. Prof. Pap. U.S., 1829.

Posamentier, H.W., Jervey, M.T., and Vail, P.R., 1988. Eustatic controls on clastic deposition, I. Conceptual framework. In Wilgus, C.K., Hastings,
B.S., Ross, C.A., Posamentier, H.W., Van Wagoner, J., and Kendall, C.G.St.C. (Eds.), Sea-Level Changes: An Integrated Approach. Spec. Publ.-Soc. Econ. Paleontol. Mineral., 42:109-124.

Reynolds, D.J., Steckler, M.S., and Coakley, B.J., 1991. The role of the sediment load in sequence stratigraphy: the influence of flexural isostasy and compaction. J. Geophys. Res., 96:6931-6949.

Steckler, M.S., and Watts, A.B., 1978. Subsidence of Atlantic-type continental margin off New York. Earth Planet. Sci. Lett., 41:1-13.

Sugarman, P.J., Miller, K.G., Owens, J.P., and Feigenson, M.D., 1993. Strontium isotope and sequence stratigraphy of the Miocene Kirkwood Formation, Southern New Jersey. Geol. Soc. Am. Bull., 105:423-436.

Tjalsma, R.C., and Lohmann, G.P., 1983. Paleocene-Eocene bathyal and abyssal benthic foraminifera from the Atlantic Ocean. Micropaleontol. Spec. Publ., 4.

Vail, P.R., and Mitchum, R.M., Jr., 1977. Seismic stratigraphy and global changes of sea level, Part 1: Overview. In Payton, C.E. (Ed.), Seismic stratigraphy-Applications to hydrocarbon exploration. AAPG Mem., 26:51-52.

van Morkhoven, F.P.C.M., Berggren, W.A., and Edwards, A.S., 1986. Cenozoic cosmopolitan deep-water benthic foraminifera. Bull. Cent. Rech. Explor-Prod. Elf-Aquitaine, Mem. 11.

Wolfe, J.A., 1992. Climatic, floristic, and vegetational changes near the Eocene/Oligocene boundary in North America. In Prothero, D.R., and Berggren, W.A. (Eds.), Eocene-Oligocene Climatic and Biotic Evolution: Princeton (Princeton University Press), 421-436.

Zachos, J.C., Breza, J.R., and Wise, S.W., 1992. Early Oligocene ice-sheet expansion on Antarctica: stable isotope and sedimentological evidence from Kerguelen Plateau, southern Indian Ocean. Geology, 20:569-573.

Zachos, J.C., Quinn, R.M., and Salamy, K., 1996. High resolution $\left(10^{4}\right.$ yr $)$ deep-sea foraminiferal stable isotope records of the Eocene-Oligocene climate transition. Paleoceanography, 11:251-266.

Date of initial receipt: 11 March 1996

Date of acceptance: 23 September 1996 Ms 150XSR-331 

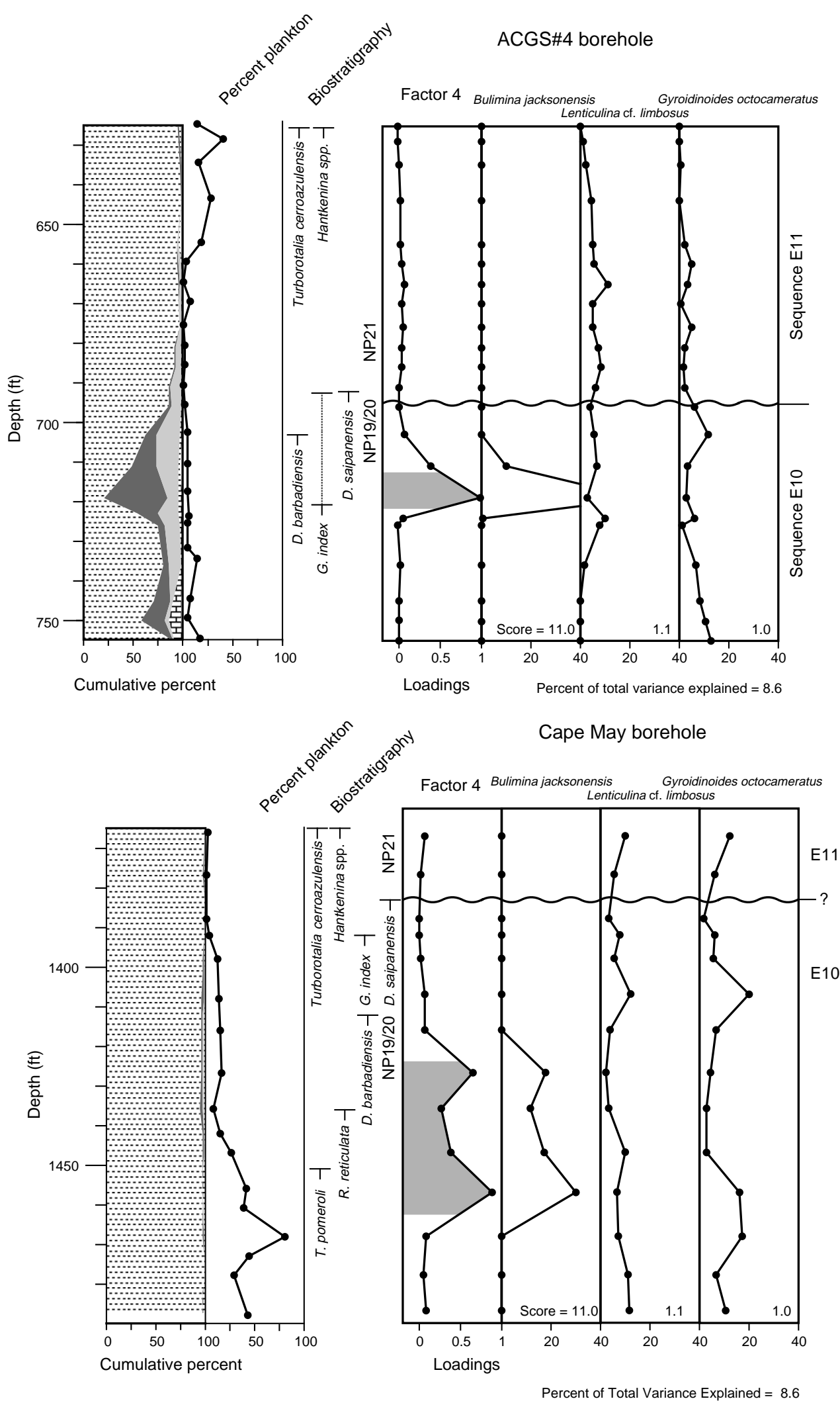

Figure 8. Species graph for Factor 4 (Bulimina jacksonensis biofacies) and related species. Distribution of species with high loadings are graphed (percent of the total sample). 


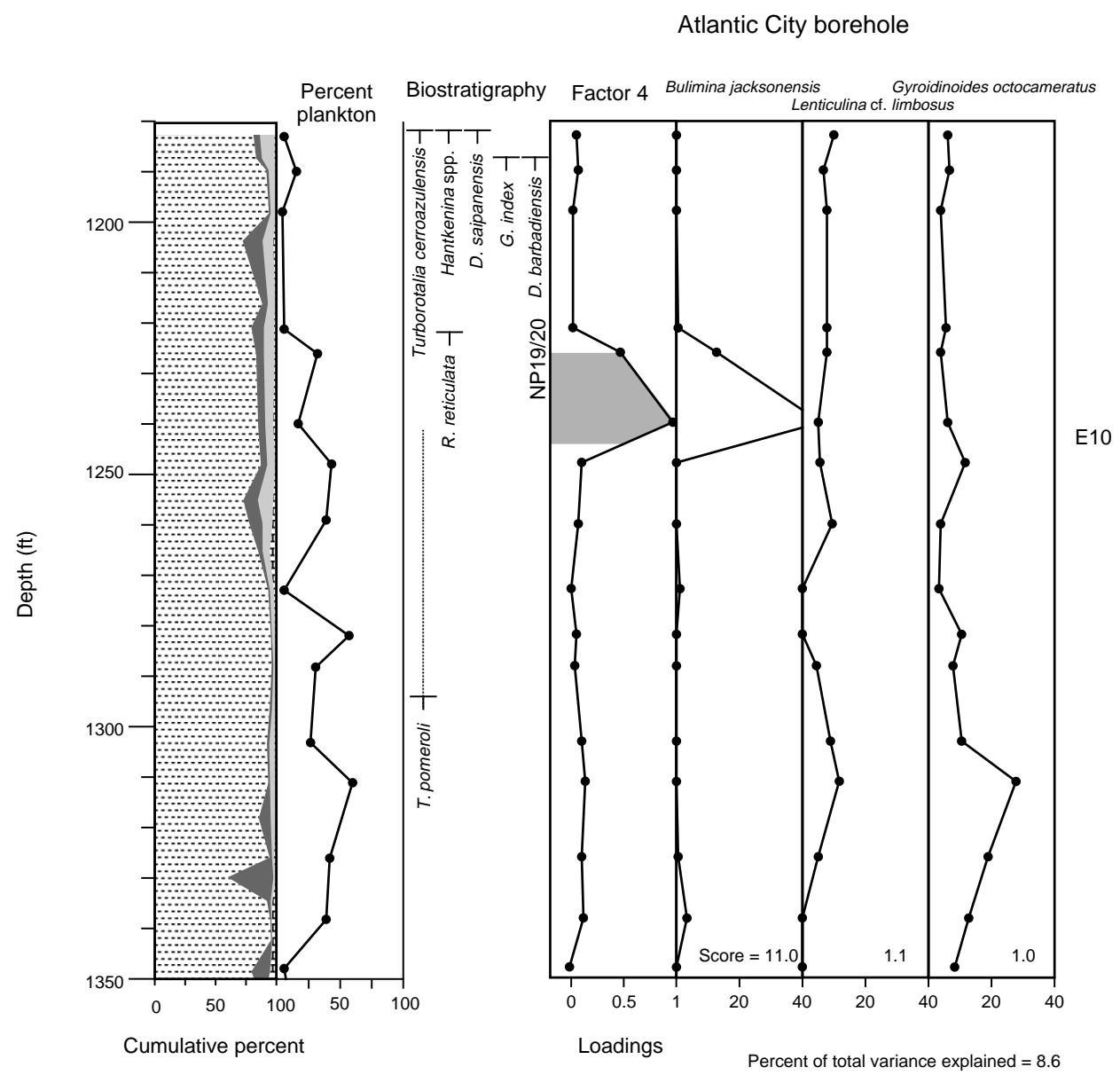

Figure 8 (continued). 

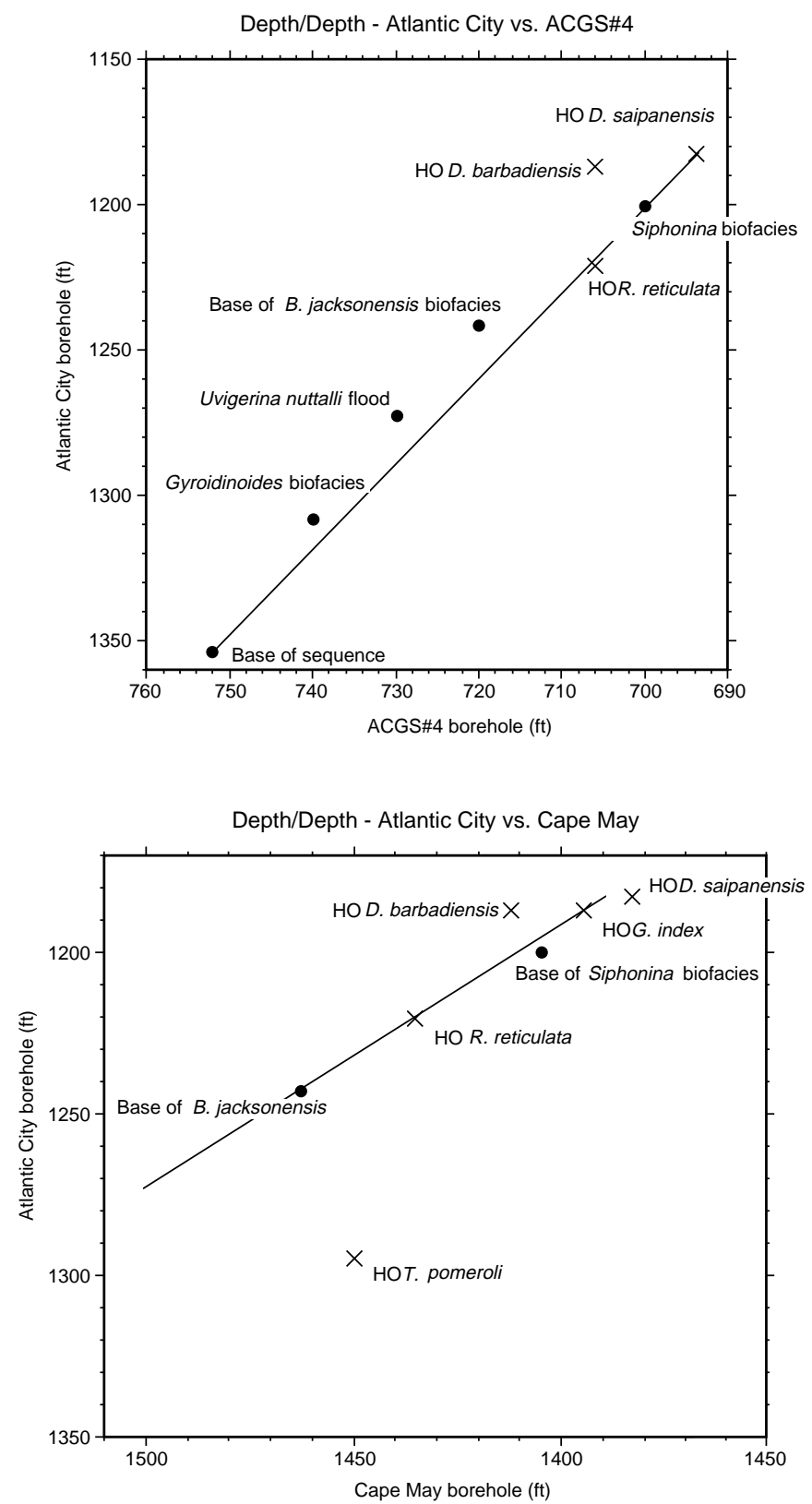

Figure 9. Depth/depth plots of time significant bioevents and locations of benthic foraminiferal biofacies. HO = highest occurrence. 
Siphonina claibornensis

Cibicidoides speciosus

Lenticulina cf. limbosus

Hoeglundina elegans

Guttulina irregularis

Ceratobulimina eximia

Hanzawaia blanpied

Globulina gibba

Marginulina cocoaensis

Cibicidoides cocoaensis

Stilostomella curvatura spinea

Eponides umbonatus

Nodosarella annulospinosa

Anomalinoides acuta

Bulimina jacksonensis

Marginulina cooperensis

Globobulimina ovata

Melonis barleanum

Oridorsalis sp.

Nonionellina winniana

Stilostomella cocoaensis

Valvulineria texana

Uvigerina multistriata

Gyroidinoides octocameratus

Hanzawaia mauricensis

Alabamina wilcoxensis

Spiroplectammina alabamaensis

Cibicides howelli

Quinqueloculina bienvillensis

Lenticulina spp.

Percent planktonic foraminifers

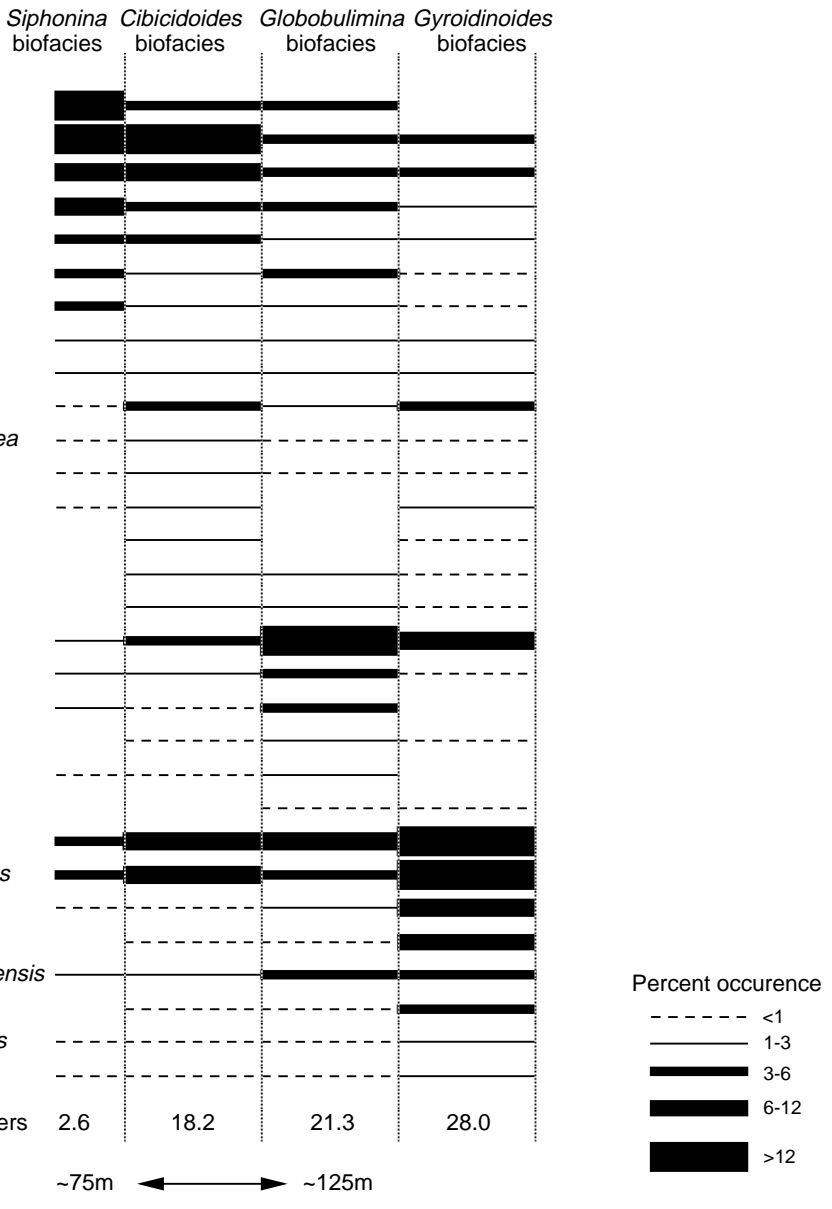

Figure 10. Depth ranges of upper Eocene benthic foraminiferal species on the New Jersey Coastal Plain. 


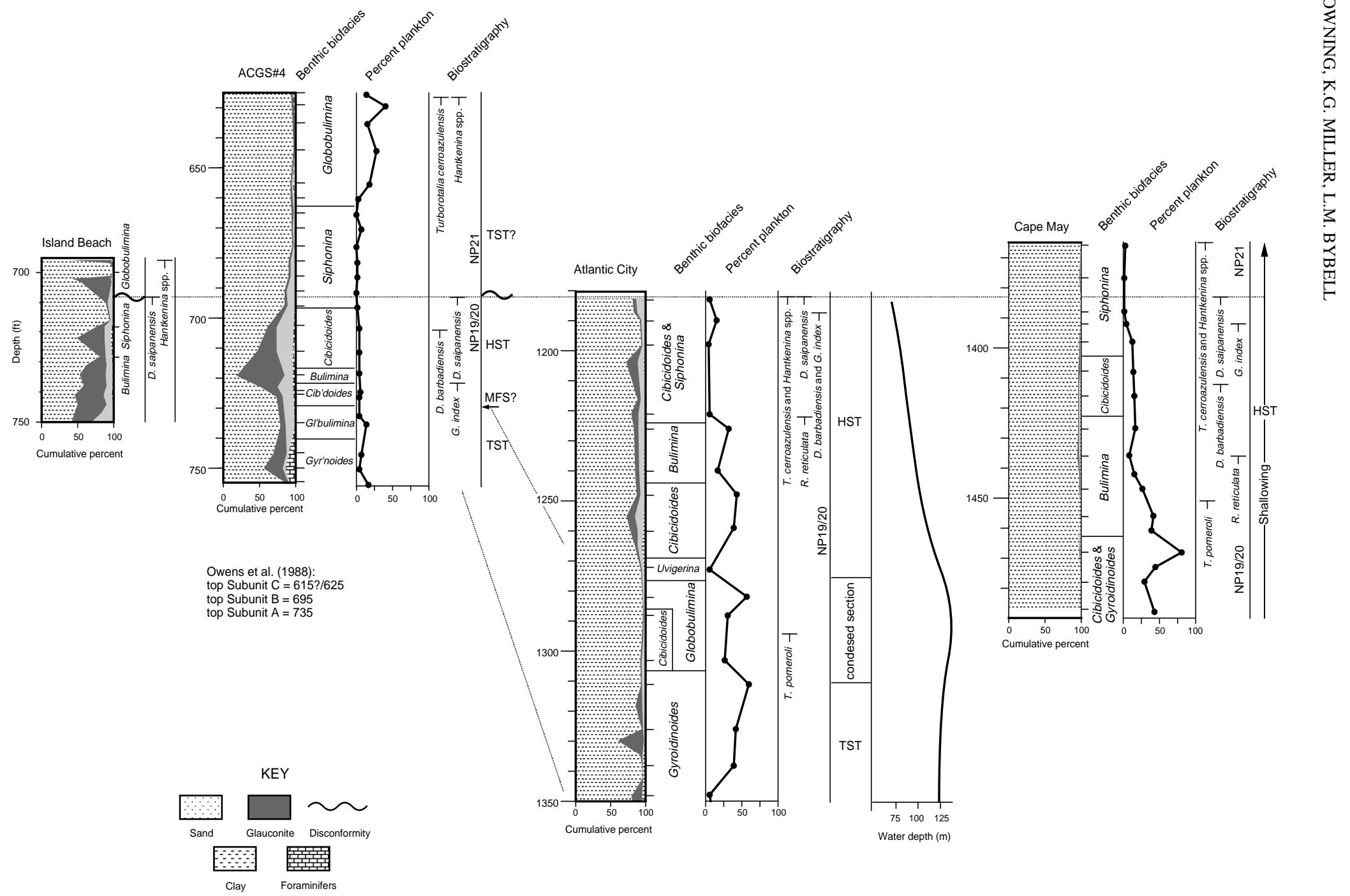

Figure 11. Comparison of lithology, benthic foraminiferal biofacies, and biostratigraphic indicators between boreholes. 
A

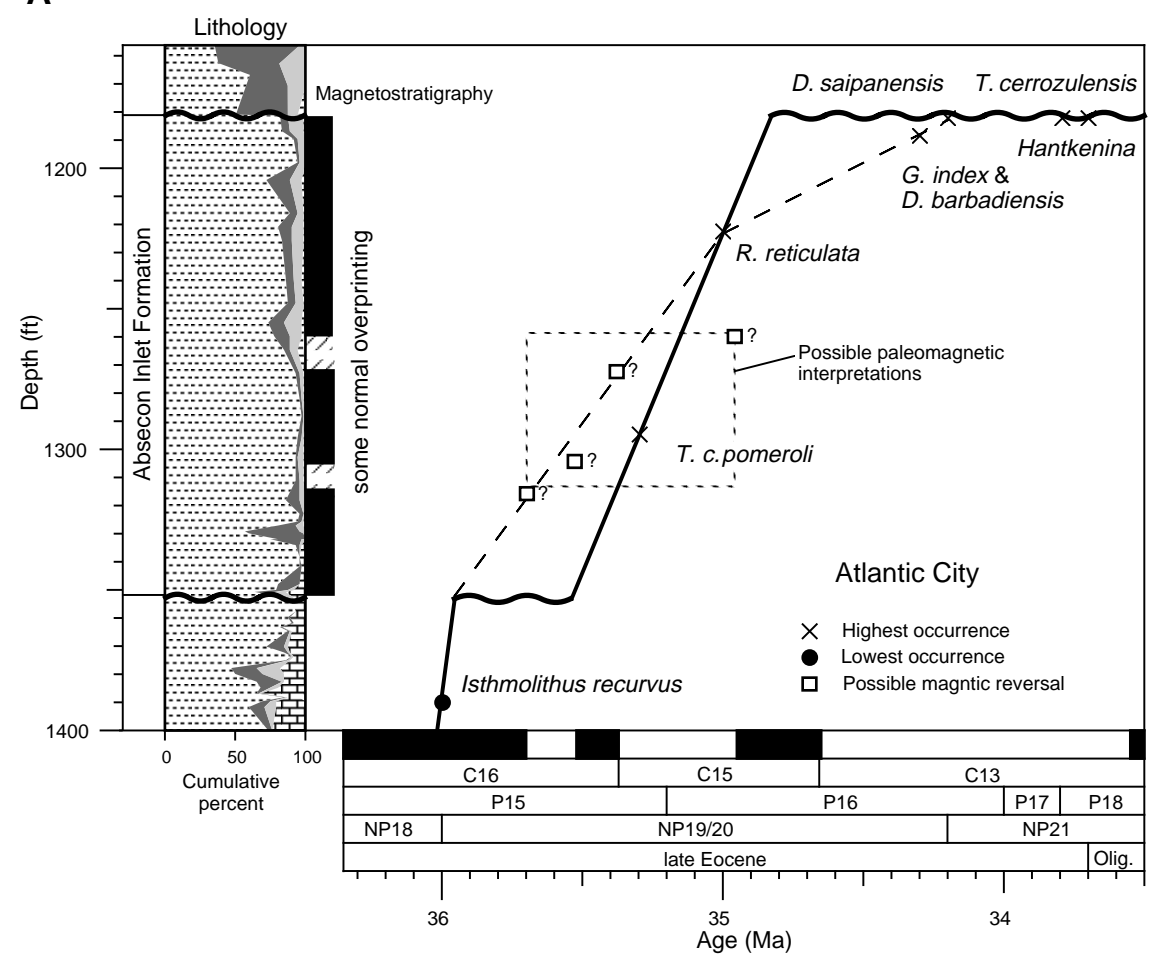

B

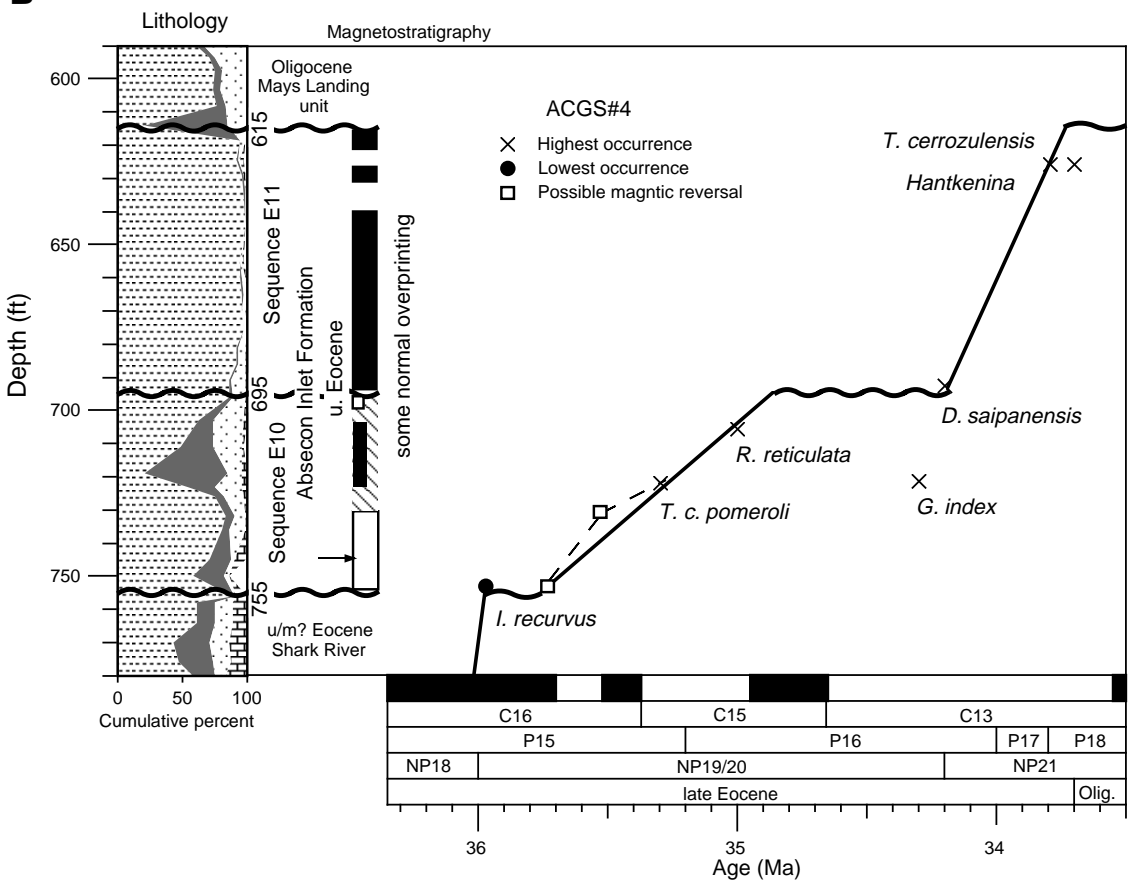

Figure 12. Age vs. depth plots for the (A) Atlantic City and (B) ACGS\#4 boreholes. The preferred interpretation is shown in a solid line. Dashed lines represent other alternatives. 


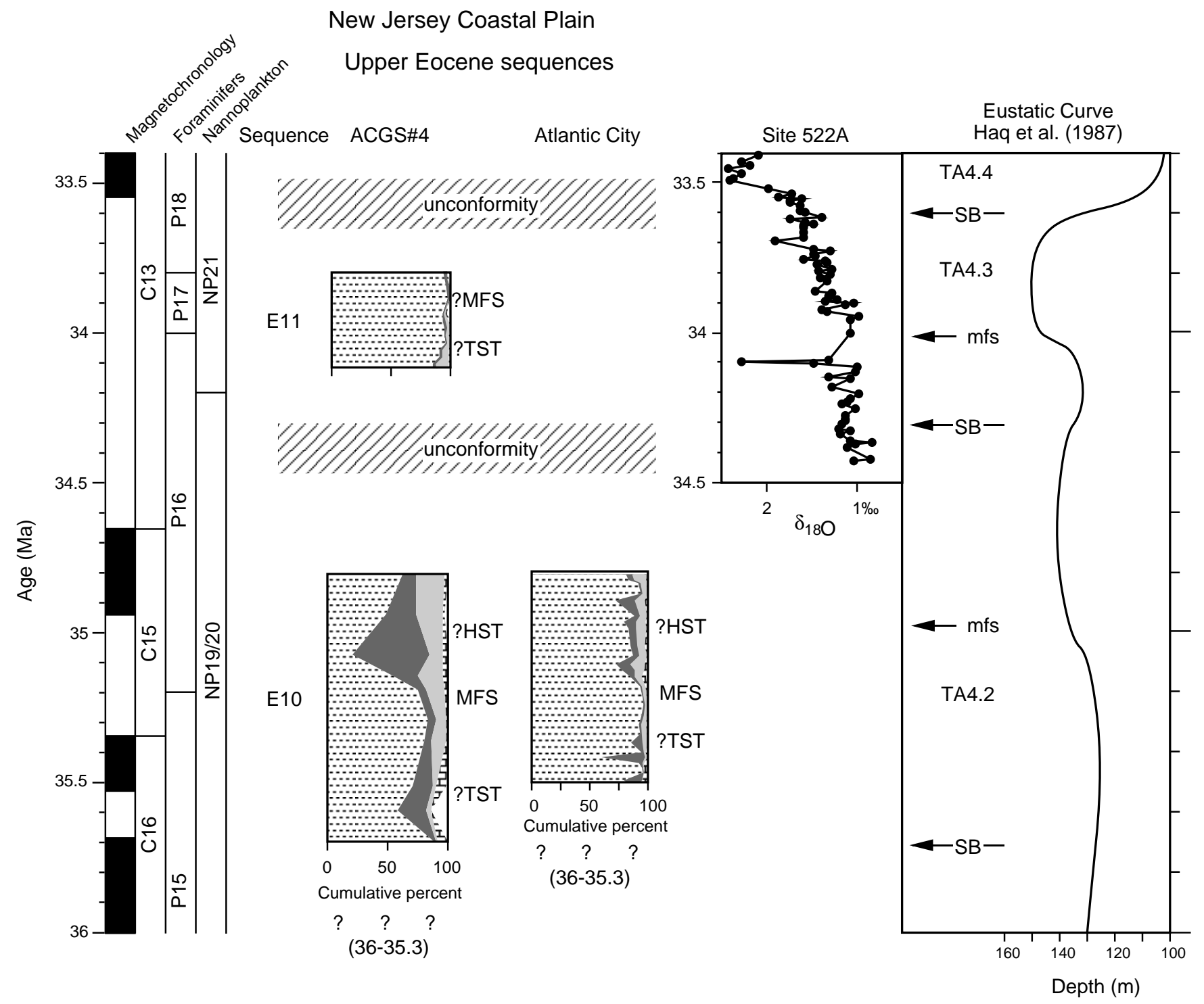

Figure 13. Distribution of sediments from the upper Eocene of the New Jersey Coastal Plain shown as a function of time and compared to the eustatic record of Haq et al. (1987), recalibrated to the time scale of Berggren et al. (1995) and the benthic foraminiferal $\delta^{18} \mathrm{O}$ record from the Atlantic Ocean (Site 522, Zachos et al., 1996). All benthic records are calibrated to Cibicidoides. 